\title{
LIVELIHOODS IN TANZANIA
}

Impact evaluation of the 'Optimizing income of local chicken and sunflower smallholder producers' project

Effectiveness Review Series ～2016/17

ANDREW ANGUKO and MASUD RANA

\section{OXFAM GB}




\section{CONTENTS}

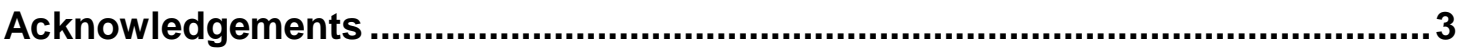

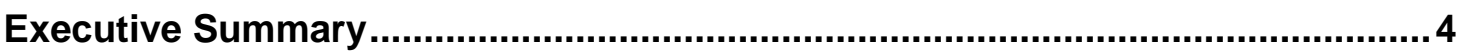

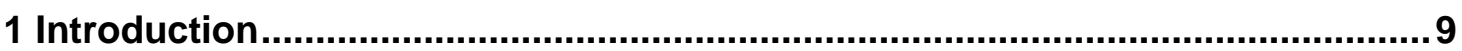

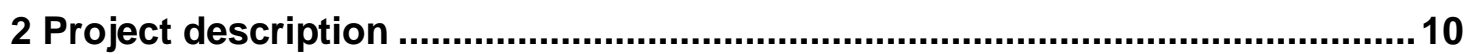

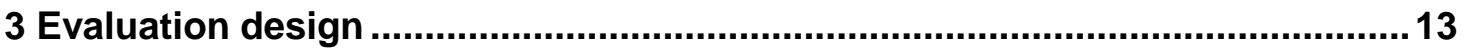

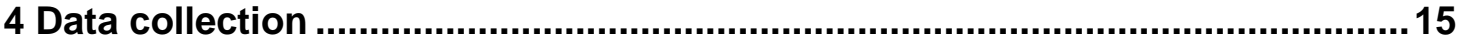

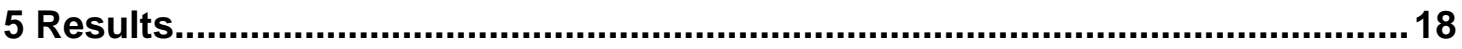

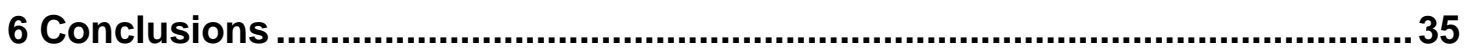

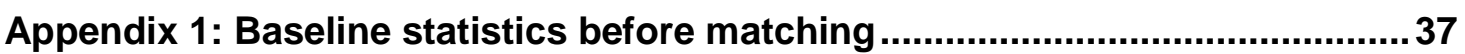

Appendix 2: Methodology used for propensity score matching ..........................39

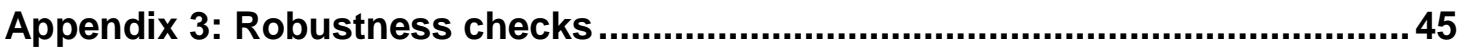




\section{ACKNOWLEDGEMENTS}

We would like to thank Oxfam in Tanzania, particularly Shija Msikula, Economic Justice Programme Coordinator, and Pamela Nyaganilwa, Logistics and Administration Assistant, for being so supportive during the exercise. Particular thanks are also due to Pantaleon Shoki, the consultant who managed the fieldwork. 


\section{EXECUTIVE SUMMARY}

Oxfam GB's Global Performance Framework is part of the organization's effort to better understand and communicate its effectiveness, as well as to enhance learning amongst staff and partners. Under this Framework, a small number of completed or mature projects are selected at random each year for an evaluation of their impact, in an exercise known as an 'Effectiveness Review'. One key focus is on the extent to which they have promoted change in relation to relevant Oxfam GB global outcome indicators.

The global outcome indicator for the livelihoods thematic area is defined as 'total household consumption per adult equivalent per day'. This indicator is explained in more detail in section 5 of this report.

The 'optimizing income of local chicken and sunflower smallholder producers' project was one of those selected for an Effectiveness Review in the 2016/17 financial year. Project activities were implemented by Oxfam GB in conjunction with local partners Uluguru Mountains Agricultural Development Project (UMADEP), Women and Poverty Alleviation in Tanzania (WOPATA), INADES Formation Tanzania (IFTz) and Social and Economic Development Initiative of Tanzania (SEDIT). The project began in October 2012 and was completed in August 2015. Its overall objective was to contribute to improved production, sales and revenue from sunflowers and chicken rearing, by providing the necessary inputs and technical advice on modern methods of farming and forming marketing groups for these commodities in order to increase sales.

The project covered three districts: Kilosa district in Morogoro region and Kongwa and Chamwino districts in Dodoma region. Local chicken production was implemented in Kilosa, while both local chicken and sunflower production initiatives were implemented in Kongwa and Chamwino districts. Sunflower was mainly grown for sale to wholesalers and local traders, with some for home consumption. Chicken production consisted of three components - eggs, chicks and live chickens. The eggs and chickens were sold to local traders and hotels, while chicks were sold to other farmers within the community.

Farmers in these districts were experiencing particular problems which led to the choice of interventions. They had poor access to markets and low capacity to produce crops or chickens, and they also lacked the necessary inputs. The local partner organizations played a key role in trying to solve these problems. For example, UMADEP built market stalls in the three districts for selling chickens, eggs and chicks and also provided project participants with incubators and brooders. It also promoted issues around women's rights and gender equality. Community resource persons (CRPs) were identified and trained and then provided with training materials to disseminate knowledge of women's rights and gender issues to the community.

Farmers were organized into farmers' groups and trained on chicken husbandry practices, as well as on how to prepare a constitution for their organizations and a business plan. 'Paravets' were selected in each ward and trained on technical aspects of delivering veterinary services, and were also supported with tools and transport to provide services to the community. In addition, incubator operators were identified and trained to serve local chicken farmers. UMADEP established a chicken smallholder producers' association at ward level, which was expected to continue to function after the partner had ended its involvement. This was intended to address sustainability issues relating to the project.

INADES formed five cooperatives for sunflower farmers. The farmers were organized to sell their seeds to cooperatives unions, in the expectation of them getting a better price for their produce. Board members for the cooperatives were appointed and trained by INADES in order to improve cooperatives' management. Cooperatives also enabled access to processing 
plants for sunflower seeds in the community - strength in numbers offered better security for farmers. The cooperatives bought sunflower seeds from farmers and took them to existing processing plants that produced sunflower oil for sale to wholesalers and retailers. Training was also offered to farmers on modern methods of sunflower production, including planting, harvesting, storage and processing.

WOPATA promoted the production of local chicken in Kilosa district through the provision of incubators, training on chicken production and the establishment of markets within the community, where local chicken could be sold to traders. It ensured that farmers had specialist knowledge on the three segments of the value chain - production of fertile eggs, incubation of eggs and rearing of chicks into chickens. 'Para-vet' services were also provided to improve chicken husbandry, diagnosis of disease, and vaccination and treatment.

Sokoine University of Agriculture in Morogoro offered training to farmers on sunflower and local chicken production in conjunction with the NGO partners and the Ministry of Agriculture. Oxfam provided the funds to implement the project and was in charge of coordinating project activities.

The project was intended to benefit up to 2,000 households in the three districts through increased agricultural productivity, value addition and sales and revenues from sunflower and local chicken production. With its support, project participants were expected to increase their output, produce higher-value goods and reach more markets. In addition, the project was designed to promote the participation of women through the development of sustainable livelihoods opportunities and to lead to an increase in household income.

\section{EVALUATION APPROACH}

The Effectiveness Review adopted a quasi-experimental impact evaluation design, which involved comparing households that had been supported by the project with households in neighbouring communities that had not been supported but had similar livelihood characteristics in 2011 , before the project was implemented.

The review was carried out in 23 villages in the three districts where project activities had been implemented. Households that had participated in the project were selected at random to be interviewed. For comparison purposes, interviews were also carried out with farmer households in four villages that had not participated, but who had been eligible and had expressed an interest in doing so.

These villages were selected purposively because they were deemed to have had similar characteristics to the implementation villages at baseline. Households in these villages were randomly selected and interviews were conducted. In total, 229 project participants and 470 non-participants were interviewed. At the analysis stage, the statistical tools of propensity score matching (PSM) and multivariate regression were used to control for demographic and baseline differences between the households surveyed in project and comparison areas, in order to increase confidence when making estimates of the project's impact.

\section{RESULTS}

The review data suggest that the project interventions made a positive contribution to the livelihoods of the target population.

One of the key questions for this review was to determine whether the project had any impact on household income and food security. This study has used 'total household consumption per adult equivalent per day' as a proxy measure of net household income. Project participants 
had a higher overall household income compared with the matched comparison group, and this difference was statistically significant. Moreover, there is some evidence to suggest that the project had a positive effect on food security, with project participants spending more on food (food consumption per adult equivalent per day) compared with the comparison households.

However, in contrast with the results for food consumption and household income, there was no evidence to suggest that the project had a significant effect on household wealth (measured by normalized wealth index). It could be reasoned from the food consumption data that the project participants spent some of their increased income on purchasing food, rather than investing in assets. It is also possible that the project participants were investing in inputs for their farm or poultry business, and hence the increased income did not translate into assets. When interpreting the results, it should also be borne in mind that savings and subsequent asset creation can also depend on cultural, social and political contexts. Changes in wealth status may require a much higher income or a longer time horizon in this particular context.

Another key aspect of the Effectiveness Review was to determine whether the project had any effect on production, sales or revenue from indigenous chicken rearing and sunflower cultivation - the two primary interventions it supported. There was some evidence that the project led to an increase in the proportion of households involved in producing eggs, which in turn led to a greater quantity of eggs being produced and sold, and greater revenues generated. There were similar results regarding the rearing and selling of chicks and live chickens.

While there was no evidence of a greater proportion of project households being involved in sunflower production, there was evidence that sunflower farmers in the sampled project areas were producing more sunflowers and generating marginally greater revenues.

An important finding was that, of the households that sold any produce, almost all reported selling some of it to local traders or middlemen. Among project households, only a very small proportion reported selling some of their produce to community associations, cooperatives or local markets. While this small proportion was still significantly higher than for comparator households, it suggests that questions must be raised regarding the effectiveness of the market interventions.

The review also considered whether farmers adopted modern agricultural practices as a result of the capacity-building training offered by the project. These agricultural practices included seed nurseries, production of compost manure, organic farming, use of improved certified seeds/seedlings, integrated and diversified farming systems and farm planning based on weather forecasts (e.g. using rain gauges). The results indicate that, on average, farmers in intervention areas adopted more of these practices than comparison households. There were also positive effects on the production of organic fertilizers and the adoption of diversified farming systems.

Although this Effectiveness Review was focused on livelihoods, some indicators were included to evaluate the impact of the project on women's participation in group activities and their influence in household decision making, given the importance of these aspects for the project logic. While there was strong evidence that the project positively affected group participation, there was no evidence that it increased women's influence in household decision-making processes.

The key results of the Effectiveness Review are summarized in Table 1. 
Table 1: Key results of the Effectiveness Review

\begin{tabular}{|c|c|c|}
\hline Outcome & $\begin{array}{l}\text { Evidence } \\
\text { of } \\
\text { positive } \\
\text { impact }\end{array}$ & Comments \\
\hline $\begin{array}{l}\text { Adoption of agricultural } \\
\text { practices and technology }\end{array}$ & Yes & $\begin{array}{l}\text { On average, farmers in the project areas adopted more } \\
\text { modern agricultural practices and technologies } \\
\text { compared with non-project areas. }\end{array}$ \\
\hline $\begin{array}{l}\text { Increased access to } \\
\text { markets }\end{array}$ & Yes & $\begin{array}{l}\text { On average, } 9 \text { percent of project participants reported } \\
\text { selling products to community associations, compared } \\
\text { with none in the comparison group. While the difference } \\
\text { was statistically significant, the small proportion of } \\
\text { project households using associations, cooperatives or } \\
\text { local markets raises questions about the project's impact } \\
\text { on overall market behaviour. }\end{array}$ \\
\hline Increased value addition & No & $\begin{array}{l}\text { No evidence of impact was found in terms of adding } \\
\text { value through food/crop processing during the project } \\
\text { period. }\end{array}$ \\
\hline $\begin{array}{l}\text { Increased production and } \\
\text { revenue from eggs }\end{array}$ & Yes & $\begin{array}{l}\text { There is evidence that project households produced and } \\
\text { sold a significantly higher number of eggs compared with } \\
\text { non-project households, leading to them receiving } \\
\text { greater revenues. }\end{array}$ \\
\hline $\begin{array}{l}\text { Increased production and } \\
\text { revenue from chicks }\end{array}$ & Yes & $\begin{array}{l}\text { There is evidence that project households produced a } \\
\text { greater number of chicks and earned greater revenues } \\
\text { from their sale. }\end{array}$ \\
\hline $\begin{array}{l}\text { Increased production and } \\
\text { revenue from local } \\
\text { chicken }\end{array}$ & Mixed & $\begin{array}{l}\text { Project households produced more chickens compared } \\
\text { with comparison families. However, there were no } \\
\text { differences in the quantity of chicken sold or the } \\
\text { revenues gained from the sales. }\end{array}$ \\
\hline Crop diversity & Yes & $\begin{array}{l}\text { Project households had slightly more diversified crop } \\
\text { portfolios. Project participants were cultivating an } \\
\text { average of } 3.05 \text { crops compared with } 2.39 \text { crops grown } \\
\text { by non-project households. }\end{array}$ \\
\hline $\begin{array}{l}\text { Increased production and } \\
\text { revenue from sunflower }\end{array}$ & Yes & $\begin{array}{l}\text { On average, project households produced more } \\
\text { sunflower than households in comparison communities, } \\
\text { but they generated only marginally more revenue. }\end{array}$ \\
\hline $\begin{array}{l}\text { Increased total crop } \\
\text { production, sales and } \\
\text { revenues }\end{array}$ & Yes & $\begin{array}{l}\text { On average, households in project areas cultivated more } \\
\text { agricultural produce and generated greater revenues } \\
\text { than matched comparison households. }\end{array}$ \\
\hline Wealth index & No & $\begin{array}{l}\text { No evidence of impact was found for changes in wealth } \\
\text { status among project households. }\end{array}$ \\
\hline $\begin{array}{l}\text { Overall household } \\
\text { income } \\
\text { (global indicator) }\end{array}$ & Yes & $\begin{array}{l}\text { Income was measured during the effectiveness review } \\
\text { indirectly through total household consumption per adult } \\
\text { equivalent per day, expressed as a logarithm of the local } \\
\text { currency (Tanzanian shilling (TSh) in this case). } \\
\text { Households in project areas had an overall household } \\
\text { income that was } 21 \text { percent higher compared with } \\
\text { households in comparison communities. }\end{array}$ \\
\hline
\end{tabular}




\section{PROGRAMME LEARNING CONSIDERATIONS}

\section{Investigate the effectiveness of the market construction initiative}

According to the project team, one of the key project interventions was the development of market structures in some of the project villages. However, findings from the review suggest that only a few of the project households interviewed sold their produce through these markets. The majority of households chose to sell their produce through local traders or middlemen. These results warrant further follow-up with both the project team and project households to examine the reasons for this, and whether there is scope to strengthen this intervention.

\section{Strengthen the role of the producer organizations and cooperatives connected to the value chains targeted by the project}

One of the project's initiatives was to establish producer organizations - particularly around the main value chains it targeted, namely sunflower, eggs and chicken. However, as with the first consideration, the findings showed that very few households sold their agricultural or livestock produce through these farmer organizations or cooperatives. Further research is required, but there seems to be scope for formalizing the remit of these organizations and examining whether there is potential to utilize the increased number of households involved in the production of these crops and poultry products. With the greater number of households involved in production, there should be a greater role for the associations to play in collective marketing and selling - potentially further boosting the strong results seen in production and revenue earned.

\section{Evaluate options for how to add value in the value chains targeted by the project}

The project was clearly successful in encouraging greater production in the value chains it targeted. This should offer a key opportunity for the project team to consider how to capitalize by evaluating options for adding value to the produce. Both in the sunflower value chain and in the chicken rearing element of the project, there seems to be great potential to increase the value of the produce, for example through the introduction of value addition machines, such as sunflower oil extractors.

\section{Review the success of the project and explore opportunities to replicate elements of it}

The results of the review indicate that the project was largely successful in its key objectives of encouraging the implementation of improved agricultural practices, increasing production in sunflower, eggs and chicken and in turn increasing overall household income. There seems to be an opportunity here to review and further understand the reasons for this success, and to evaluate whether there are opportunities to replicate the success of these interventions elsewhere. 


\section{INTRODUCTION}

Oxfam GB has put in place a Global Performance Framework (GPF) as part of its effort to better understand and communicate its effectiveness, as well as to enhance learning across the organization. The GPF requires project and programme teams to report output data annually across six thematic indicator areas. In addition, every year, for each thematic indicator area a small number of mature projects are randomly selected to be evaluated through rigorous Effectiveness Reviews. 1 One key focus is on the extent to which they have promoted change in relation to relevant Oxfam GB global outcome indicators.

The global outcome indicator for the livelihoods thematic area is defined as total household consumption per adult equivalent per day. This indicator is explained in more detail in section 5 of this report.

This Effectiveness Review, which was conducted in July 2016, was intended to evaluate the success of the project 'optimizing income of local chicken and sunflower smallholder producers' in promoting food security and strengthening production and marketing of sunflower and local chicken among project participants.

The project took place in three districts in Tanzania - Kongwa and Chamwino in Dodoma region and Kilosa in Morogoro - between October 2012 and August 2015. It was implemented by Oxfam in conjunction with local partners Uluguru Mountains Agricultural Development Project (UMADEP), Women and Poverty Alleviation in Tanzania (WOPATA), INADES Formation Tanzania (IFTz), Social and Economic Development Initiative of Tanzania (SEDIT), the Ministry of Agriculture of the Republic of Tanzania and Sokoine University of Agriculture in Morogoro. It was intended to benefit up to 2,000 households in the three districts through increased agricultural productivity, increased value addition and increased sales and revenues. With support from the programme, project participants were expected to increase their output, produce higher-value goods and reach more markets. The project also sought to promote women's participation through the development of sustainable livelihoods opportunities.

This report presents the findings of the Effectiveness Review. Section 2 briefly reviews the design of the project. Section 3 describes the design used for the evaluation, and section 4 describes how this design was implemented. Section 5 presents the results of the data analysis, based on a comparison of outcome measures between the intervention and comparison groups. Section 6 concludes with a summary of the findings and some considerations for programme learning. Finally, baseline statistics before matching are provided in Appendix 1; technical and methodological considerations on the propensity score matching (PSM) approach are given in Appendix 2; and tests on the robustness of the results are examined in Appendix 3. 


\section{PROJECT DESCRIPTION 2.1 PROJECT ACTIVITIES}

Oxfam has embarked on an agricultural scale-up programme to contribute to poverty reduction efforts in three districts in the United Republic of Tanzania - Kilosa district in Morogoro region and Kongwa and Chamwino districts in Dodoma region - through reaching smallholder farmers using a market-based value chain approach. Agriculture and small household businesses provide livelihoods for the majority of the population of these two regions, and at least 90 percent of the population are farmers.

One of the barriers to improved production was the low level of skills and knowledge of modern agricultural practices and markets in indigenous communities. Commodities such as sunflower and local chicken are being promoted by international agencies like Oxfam so that people can attain self-sufficiency in food production and improve revenues to boost household incomes.

This project was funded by the "La Caixa" Foundation and implemented by Oxfam together with local partner organizations. The programme covered eight villages in Dodoma region, four each in Kongwa and Chamwino districts, and 10 villages in Kilosa district in Morogoro region. The programme was implemented from October 2012 to August 2015.

The main crop that was promoted was sunflower, although farmers in project areas also cultivate maize, rice, bananas, vegetables, cassava, sweet potato and coconut. The local partners provided tools, seeds and training on modern methods of agricultural production. Oxfam provided the funds and also took a lead in coordinating implementation of the project activities.

The activities implemented included strengthening households' links to markets, the provision of cultivation, harvesting and processing tools, technical assistance on farming techniques and the provision of market information and credit facilities to farmers. Markets were also built in the villages where farmers could sell their agricultural produce. Some produce was sold to wholesalers and retailers and some was consumed locally. 'Para-vet' services were also established for the improvement of local chicken husbandry practices, the management of diseases and vaccinations and treatments. Brooders and incubators were provided for eggs and chicks in the project areas. Issues around women's rights and gender equality were also addressed. Local chicken smallholder producers were organized into groups and trained on chicken husbandry practices, and on how to prepare a constitution and a business plan. A chicken smallholder producers' association was formed and boards were created at ward level to manage project activities.

Oxfam and its local partners worked with these groups and associations for effective and efficient management of the project. The programme aimed to improve the livelihoods of approximately 2,000 households in the three districts by strengthening production systems for sunflower and local chicken.

In addition, Community resource persons (CRPs) were identified and trained and then provided with training materials to disseminate knowledge of women's rights and gender issues to the community. 


\subsection{PROJECT LOGIC AND INTENDED OUTCOMES}

This section describes how the project was intended to achieve its goals. Using existing project documentation, as well as through discussions with the implementing team, it is possible to map out the intended causal links from project activities, via outputs and intermediate outcomes to changes in overall household income. This results in the project logic model shown in Figure 2.1.

\section{Figure 2.1: Project logic model}

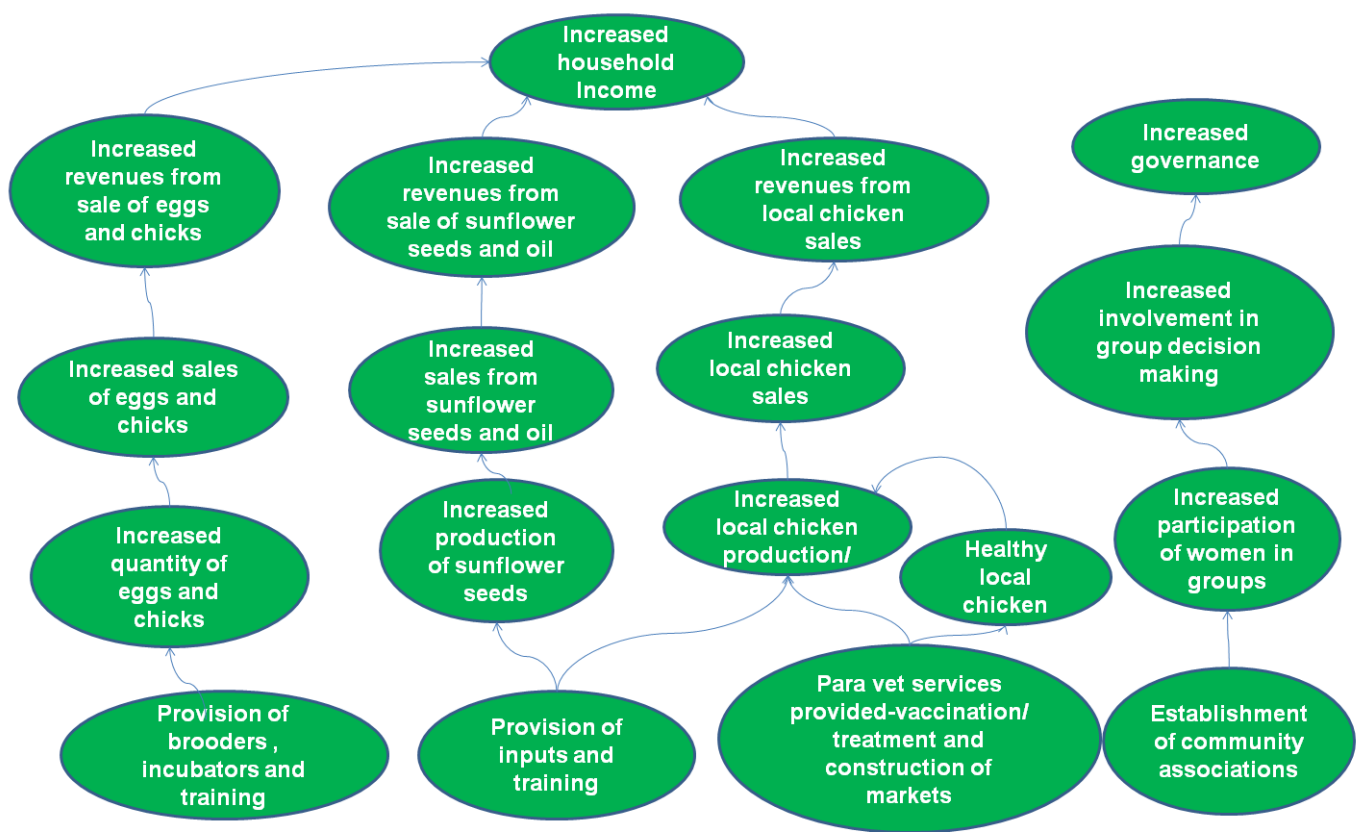

Project logic plays an important role in the design of quantitative evaluations. It is an explicit theory or model of how the project causes the intended or observed outcomes. It identifies project resources, project activities and intended project outcomes, and specifies a chain of hypothetical causal assumptions linking programme resources, activities, intermediate outcomes and ultimate project goals.

Project logic is important as a project's success or failure can be assessed only with a clear understanding of the problem it was intended to address, the rationale for choosing a particular approach and how the project was expected to operate.

In this case, the project was expected to increase household income and food security through improvements in sunflower and local chicken production and marketing. This was supported by interventions, including various trainings, to build the capacity of farmers to use modern agricultural practices, the provision of inputs - such as seeds, tools, brooders and incubators and improvements to local marketing and construction of markets in the communities.

According to the project logic, higher production and increased sales were expected to lead to better revenues and hence to increased income for the households involved in the project. At the same time, membership of associations and the construction of markets aimed to ensure that farmers had somewhere they could market their produce; this was expected to enhance sales and revenues, and ultimately lead to increased household income. The provision of brooders and incubators was expected to increase egg and chick production, leading to increased sales and revenues from local chicken. 
Attempts were also made to increase the participation of community members in the project, especially women. With increased membership and participation in groups, women were expected to be able to better influence decisions that affected their livelihoods and communities.

Based on this project logic, the Effectiveness Review sought to answer the following key evaluation questions:

- Did the farmers adopt modern methods of crop production, agricultural technology and processing of crops for value addition before selling?

- Was there increased access to markets for farmers involved in the project?

- Was there a difference between participants and non-participants in the quantities of sunflower, eggs, chicks and chicken produced and sold and the revenues obtained?

- What was the effect of the project on the overall household income of the participants?

It was particularly important to investigate the drivers of expected changes in outcomes, such as training received and agricultural practices adopted, value addition, access to markets and access to technology. 
The central problem in evaluating the impact of any project is how to compare the outcomes that result from that project with what would have been the case without that project having been carried out. In the case of this Effectiveness Review, information about the lives and livelihoods of project participants was collected through a household questionnaire - but clearly it was not possible to observe what their situation would have been had they not had the opportunity to participate in the project. In any evaluation, that 'counterfactual' situation cannot be directly observed: it can only be estimated.

In the evaluation of programmes that involve a large number of units (whether individuals, households or communities), it is common practice to make a comparison between units that were subject to the programme and those that were not. As long as the two groups can be assumed to be similar in all respects except for the implementation of the specific project, observing the situation of those where the project was not implemented can provide a good estimate of the counterfactual.

An ideal approach in evaluating a project such as this would have been to select at random the areas in which the project was to be implemented. Random selection minimises the probability of there being systematic differences between the project participants and nonparticipants, and so maximises confidence that any differences in outcomes are due to the effects of the project.

In the case of the project examined in this Effectiveness Review, however, the villages involved were not selected at random; in fact, villages were deliberately chosen based on them being particularly vulnerable in terms of low quantity and quality of agricultural production, lack of agricultural inputs, poor use of modern methods of crop production, low revenues and lack of access to markets.

However, discussions with the implementation staff revealed that there were neighbouring villages where farmers would have been eligible to participate in the project and had the potential to benefit from it, but were not given the opportunity to participate. These farmers, therefore, did not benefit from the project even though they had livelihoods characteristics similar to those of the project participants at baseline. This allowed a 'quasi-experimental' evaluation approach to be adopted, in which the situation of farmers in non-project villages was assumed to provide a reasonable counterfactual for the situation of farmers who had participated in the project activities.

To improve confidence in making this comparison, households participating in the project were 'matched' with households that had similar characteristics in the non-project (or 'comparison') villages. Matching was performed on the basis of a variety of characteristics - including household size, level of education and indicators of material well-being, such as housing conditions and ownership of assets. Since some of these characteristics may have been affected by the project itself (particularly characteristics relating to wealth indicators), matching was performed on the basis of these indicators before the implementation of the project. Baseline data were not available, and so survey respondents were asked to recall some basic information about their household's situation in 2011, before the project was implemented. While these recall data are unlikely to be completely accurate, this should not lead to significant bias in the estimates as long as the measurement errors due to the recall data are not significantly different for the project participants and the comparison group.

Recall survey data provided a variety of baseline household characteristics on which matching could be carried out. These characteristics were used to calculate a 'propensity score', which is the conditional probability of the household being a participant, given the set of observable characteristics in the baseline. Project households and comparison households were then 
matched based on them having propensity scores within certain ranges. Appendix 2 provides a more extensive explanation of the matching procedure and tests carried out after matching to assess whether baseline characteristics were similar between the two groups.

As a check on the results derived from the propensity score matching (PSM) process, results were also estimated using multivariate regression models. Like PSM, multivariate regression also controls for measured differences between intervention and comparison groups, but it does so by isolating the variation in the outcome variable explained by being a project participant, after the effects of other explanatory variables have been accounted for. The regression models tested are described in Appendix 3.

It should be noted that both PSM and multivariate regression rely on an assumption that the 'observed' characteristics (those that are collected in the survey and controlled for in the analysis) capture all of the relevant differences between the two groups. If there are 'unobserved' differences between the groups that matter for project participation, then estimates of outcomes derived from them may be misleading. Unobserved differences between the groups could potentially include differences in attitudes or motivation (particularly important when individuals have taken the initiative to participate in a project), differences in community leadership or local-level differences in weather or other contextual conditions faced by households.

The choice of which intervention and comparison villages to survey for this Effectiveness Review was made principally to minimize the potential for any such unobservable differences to bias the results. 


\section{DATA COLLECTION}

\subsection{SAMPLING APPROACH}

The intervention group consisted of farmer households cultivating maize, rice, groundnuts and beans that participated in the project from inception to closure. Participants in the intervention group were selected based on their vulnerability, as explained in section 3 . Since it was not possible to include all villages in the project due to insufficient resources, some villages within the selected districts did not take part in the project activities even though they were also vulnerable. Households from these villages therefore formed the comparison group.

The project was implemented in Kongwa and Chamwino districts in Dodoma region and Kilosa district in Morogoro region. In Kongwa district, the project focused on local chicken and sunflower production, while in Chamwino and Kilosa it concentrated solely on local chicken.

Lists of participating households in the villages sampled in Kongwa, Chamwino and Kilosa were obtained from the local partners. The number of households to be selected from each of the villages was determined by dividing the total number of households in each village by the number of participant households in the selected villages and multiplying by the sample size that had been determined for the intervention group. The sample frame was constructed by identifying those households that received at least one project intervention. Among the households that benefited directly from the project, 229 were randomly selected to be interviewed. The number of households selected for the survey from each of the project villages is shown in Table 4.1.

There were villages in Kongwa and Kilosa districts that did not participate in the project, but could have participated since they were similar to those that did take part. The project staff and partners identified two villages in Kongwa district in Dodoma region and three villages in Kilosa in Morogoro region that did not participate in the project but had similar livelihoods characteristics to those of the project participants. These villages therefore provided good comparison households, to the best knowledge of the project staff. A total of 470 households were randomly selected to be interviewed. Similarly, the number of households from the respective comparison villages are shown in Table 4.1.

The comparison villages were selected purposively. Households were, however, randomly selected from the comparison villages using the random walk sampling method. This involves first selecting a starting point where an interviewer would begin the interviews, observing the following rules: starting points were chosen using a landmark, such as a church, school or road junction or any other identifiable mark; starting points were spread all over the sampling area and were not close to each other; no road was 'walked on' for a second time until all the roads in the village had been 'walked on'; if a selected starting point did not fulfil one of the above requirements, the next road had to be selected, and if this was not suitable the next had to be chosen, and so on, until the right point was reached. The interviewer would begin by going to a starting point provided by the field supervisor. As the enumerator walked along the road, they sampled at systematic intervals defined by the supervisor (e.g. after every five households, depending on the distribution of households in the village). This method was employed because there were no household lists in comparison villages.

A household questionnaire was developed by Oxfam staff, in collaboration with partners, to capture data on various outcome measures associated with the project's activities.

Demographic data and recalled baseline data were also collected to statistically control for differences between the supported and comparison households that could not plausibly be affected by the project. The questionnaire was pre-tested by local Oxfam staff and then by the enumerators during a practice exercise, and was revised accordingly. Data collection involved 
the use of mobile devices using SurveyCTO software. This software uses an Excel platform where the survey is developed, uploaded onto the server and then downloaded onto mobile devices. The advantage of this method is that data collection can be done offline and, at the end of the day, the completed records can be sent to the server online. The use of mobile devices reduces the cost and time taken for data collection and, more importantly, reduces the errors associated with data entry.

The enumerators participated in a three-day training workshop, which was led by Oxfam staff. The first and second days of the workshop involved training using the paper questionnaire and mobile phone devices respectively. The third day involved a piloting exercise, in which a community in Dodoma was identified. Following this exercise, the performance of each of the enumerators was reviewed individually before their appointments were confirmed. The full list of villages, with numbers of households/farmers interviewed in intervention and comparison villages, is shown in Table 4.1.

Table 4.1: Intervention and comparison groups - sample sizes

\begin{tabular}{|c|c|c|c|c|c|c|}
\hline \multirow[b]{2}{*}{ District } & \multicolumn{3}{|c|}{ Project participants } & \multicolumn{3}{|c|}{ Sample comparison group } \\
\hline & $\begin{array}{l}\text { Villages/farmer } \\
\text { associations } \\
\text { randomly } \\
\text { selected from } \\
\text { the three } \\
\text { project districts }\end{array}$ & $\begin{array}{l}\text { Households/ } \\
\text { farmers } \\
\text { participating } \\
\text { in the } \\
\text { project }\end{array}$ & $\begin{array}{l}\text { Households } \\
\text { / } \\
\text { farmers } \\
\text { interviewed }\end{array}$ & District & $\begin{array}{l}\text { Villages/farmer } \\
\text { associations } \\
\text { selected in } \\
\text { comparison } \\
\text { communities }\end{array}$ & $\begin{array}{l}\text { Households/ } \\
\text { farmers } \\
\text { interviewed } \\
\text { in } \\
\text { comparison } \\
\text { communities }\end{array}$ \\
\hline \multirow[t]{4}{*}{ Kongwa } & Banibani & 54 & 10 & Kongwa & Songambele A & 81 \\
\hline & Mkutani & 30 & 6 & & Songambele B & 79 \\
\hline & Sejeli & 130 & 28 & & & \\
\hline & Msunjilile & 43 & 8 & & & \\
\hline \multirow[t]{4}{*}{ Chamwino } & Ikowa & 32 & 5 & Chamwino & & \\
\hline & Makaja & 15 & 3 & & & \\
\hline & Mgunga & 18 & 3 & & & \\
\hline & Chinangali & 122 & 21 & & & \\
\hline \multirow[t]{10}{*}{ Kilosa } & Unone & 44 & 7 & Kilosa & Mbwade & 108 \\
\hline & Batini & 33 & 5 & & Lumbiji & 90 \\
\hline & Peapea & 65 & 11 & & Majambaa & 102 \\
\hline & Parakuyo & 56 & 9 & & & \\
\hline & Msowero & 212 & 38 & & & \\
\hline & Idole & 76 & 15 & & & \\
\hline & Karandasi & 65 & 10 & & & \\
\hline & Mfulu & 258 & 42 & & & \\
\hline & Kimamba & 43 & 7 & & & \\
\hline & Madudu & 64 & 9 & & & \\
\hline Total & & 1,352 & 229 & & & 470 \\
\hline
\end{tabular}




\subsection{ANALYSIS}

Households of project participants and non-participants were compared in terms of their demographic characteristics, livelihoods activities and economic situations in 2011. These data were based on information either recalled during the questionnaire or reconstructed from the household composition at the time of the survey.

The full comparison is shown in Appendix 1. Some important differences were found between project participants and non-participants. For example, on average, the households in the project villages were larger and contained a higher number of adults. Also, the proportion of households in the wealthiest quintile in 2011 was significantly higher in project villages than in non-project villages, and conversely the proportion of project households in the poorest quintile was lower than for comparison households. In addition, educational achievement was generally higher among project households and, importantly, a much greater proportion of households in the project areas were already poultry farmers in 2011. These differences that existed before the project had the potential to bias any comparison between the project and comparison groups. It was therefore important to control for these baseline differences when making such comparisons.

As explained in section 3, the main approach used in this Effectiveness Review was propensity score matching (PSM). The variables on which respondents were matched were selected from among the full list detailed in Appendix 1, based on two key factors. Firstly, those variables were selected that were thought to be the most significant in influencing respondents' participation in the project. Secondly, the review team aimed to include variables that could affect potential project outcomes as well as the likelihood of participating in the project. The list of matching variables selected and full details of the matching procedure applied are described in Appendices 1 and 2.

After matching, households in the project and comparison groups were reasonably well balanced in terms of the recalled baseline. One caveat is that 10 of the 229 project households in the sample had to be dropped from the analysis. The consequence of this is that the estimates of the project's impact presented in section 5 are not a fully representative sample of households in the project communities, as they exclude a small, non-random minority.

All the results described in section 5 of the report were also tested for robustness by estimating them with various alternative PSM models and linear or probit regression models. These robustness checks are shown in Appendix 3. The alternative models produced results that were all similar (in size and in statistical significance) to those presented in the tables in section 5 .

It is important to recall, as highlighted in section 3, that PSM and regression models can control only for the baseline differences between the households in project and comparison communities for which data were collected in the survey. If there were any 'unobserved' preexisting differences between the two groups - such as individuals' attitudes, motivations, skills or confidence - then these may have biased the estimates of outcomes described in section 5 . The evaluation design and the selection of respondents were intended to minimize any potential for unobserved differences, but this possibility cannot be excluded and must be borne in mind when interpreting the results. 


\section{RESULTS}

This report is intended to be free from excessive technical jargon, with more detailed technical information being restricted to the appendices and endnotes. However, there are some statistical concepts that cannot be avoided in discussing the results. In this report, results are usually stated as the average difference between households living in villages where the project was implemented (referred to as the 'intervention group') and the matched households in villages where the project was not implemented (the 'comparison group').

In the tables of results on the following pages, statistical significance is indicated with asterisks, with three asterisks $\left(^{* * *}\right)$ indicating a $p$-value of less than 1 percent, two asterisks $\left({ }^{* *}\right)$ indicating a p-value of less than 5 percent and one asterisk $\left(^{*}\right)$ indicating a p-value of less than 10 percent. The higher the $p$-value, the less confident the review team can be that the measured estimate reflects the true impact. Results with a $p$-value of more than 10 percent are not considered to be statistically significant.

\subsection{INTRODUCTION}

This section presents a comparison of the project participants and non-participants in terms of various outcome measures relating to the project under review. The results are shown after correcting for the baseline and demographic differences described in section 4.2 using a PSM procedure. The details of this procedure are described in Appendix 2. All outcomes discussed here have also been tested for robustness using alternative statistical models, as described in Appendix 3. The alternative models produced results that were similar (in size and in statistical significance) to those presented in the tables in this section.

It is important to stress that the results presented in this section are average results across all the sampled intervention households. Clearly, it would be of interest to investigate the effects of the project at a more local level and for specific sub-groups, but the small sample sizes limit the potential for detecting any differences between these various sub-groups.

There are two key limitations to the analysis, which have been described above but are repeated here because they affect the interpretation of the results:

1. A non-random minority of households were excluded from the analysis during the matching process (10 of 229 intervention group households and 35 of the 468 comparison group households; two of these comparison households were excluded due to the lack of identifier data). This means that the results shown in the tables in this section are not based on the full sample of households interviewed in the project communities.

2. There may be 'non-observable' differences between the project participants and comparison households - such as individuals' attitudes or motivations, differences in local leadership, weather, market fluctuations or other contextual conditions. If these unobserved differences also influence the potential outcomes considered in this section, then the estimates of the project's effects will be biased. This possibility must be borne in mind when interpreting the results. 


\subsection{INVOLVEMENT IN PROJECT ACTIVITIES}

Before considering outcome-level changes, it is necessary to consider the proportion of respondents who reported exposure to project-related interventions. This is an important consideration as, firstly, it represents the analysis of the first step of the project's theory of change: i.e. are project participants being exposed to the intended interventions? Secondly, it is important to assess whether respondents in comparison areas also reported receiving such support in their communities, as this may have an effect on the differences that might be detected between the intervention and comparison groups in the outcome measures reported subsequently. The following activities were considered in the analysis for the intervention and comparison households:

- provision of sunflower seeds for planting

- formal market structures/buildings established

- facilitated to be member of the VICOBA group (a savings group organisation)

- access to chicken brooders

- access to chicken incubators

- provision of chickens for egg production

- provision of fertile eggs for incubation

- organization of trading/market fairs/farmers' field days

- technical support

- women's training/empowerment events (e.g. gender sensitivity/awareness/women's rights).

Table 5.1 shows the differences between the project and comparison households in terms of their participation in project activities. It should be noted that these figures are presented after correcting (as far as possible) for the baseline and demographic differences between the intervention and comparison respondents, using the PSM process described in Appendix 2.

Respondents were asked whether they or any member of their household had taken part in any of the activities mentioned in Table 5.1. It is evident from the findings that a much greater proportion of the project participants received the different elements of project support compared with comparison households. Of particular note is that 50 percent of project households received sunflower seeds for planting (column 1), 34 percent received chickens for egg production (column 5) and 39 percent received fertile eggs for incubation (column 6).

\section{Table 5.1: Involvement in project activities}

\section{Part A}

\begin{tabular}{|c|c|c|c|c|} 
& $\begin{array}{c}\text { Received } \\
\text { sunflower seeds } \\
\text { for planting (\%) }\end{array}$ & $\begin{array}{c}\text { Received } \\
\text { technical } \\
\text { support (\%) }\end{array}$ & $\begin{array}{c}\text { Received support } \\
\text { to access } \\
\text { agricultural credit } \\
(\%)\end{array}$ & $\begin{array}{c}\text { Attended } \\
\text { farmers' field } \\
\text { days (\%) }\end{array}$ \\
\hline Intervention group mean & 0.50 & 0.14 & 0.16 & 0.44 \\
\hline Comparison group mean & 0.07 & 0.01 & 0.01 & 0.03 \\
\hline Difference: & $0.43^{\star * *}$ & $0.13^{\star \star \star}$ & $0.15^{\star \star *}$ & $0.42^{\star \star *}$ \\
\hline Observations (intervention & $(0.08)$ & $(0.04)$ & $(0.04)$ & $(0.05)$ \\
\hline group) & 219 & 219 & 219 & 219 \\
\hline Observations (total) & 654 & 654 & 654 & 654 \\
\hline
\end{tabular}


Standard errors clustered at village level in parentheses; ${ }^{*} p<0.1,{ }^{* *} p<0.05,{ }^{* * *} p<0.01$; PSM estimates are bootstrapped with 1,000 repetitions.

\section{Part B}

\begin{tabular}{|c|c|c|c|c|}
\hline & $\begin{array}{c}5 \\
\text { Received } \\
\text { chickens for egg } \\
\text { production (\%) }\end{array}$ & $\begin{array}{c}6 \\
\text { Received } \\
\text { fertile eggs } \\
\text { for } \\
\text { incubation } \\
(\%)\end{array}$ & $\begin{array}{c}7 \\
\text { Had access to } \\
\text { chicken } \\
\text { brooder (\%) }\end{array}$ & $\begin{array}{c}\mathbf{8} \\
\text { Had access } \\
\text { to incubators } \\
(\%)\end{array}$ \\
\hline Intervention group mean & 0.34 & 0.39 & 0.47 & 0.49 \\
\hline Comparison group mean & 0.01 & 0.00 & 0.01 & 0.01 \\
\hline Difference: & $0.33^{\star \star *}$ & $0.39^{\star \star *}$ & $0.46^{\star \star *}$ & $0.49^{\star \star \star}$ \\
\hline Observations (intervention & $(0.05)$ & $(0.08)$ & $(0.07)$ & $(0.07)$ \\
\hline group) & 219 & 219 & 219 & 219 \\
\hline Observations (total) & 654 & 654 & 654 & 654 \\
\hline
\end{tabular}

Standard errors clustered at village level in parentheses; ${ }^{*} p<0.1,{ }^{* *} p<0.05,{ }^{* * *} p<0.01$; PSM estimates are bootstrapped with 1,000 repetitions.

\section{Part C}

\begin{tabular}{|c|c|c|c|}
\hline & $\begin{array}{c}\mathbf{9} \\
\text { Had access to } \\
\text { established market } \\
\text { structures (\%) }\end{array}$ & $\begin{array}{c}10 \\
\text { Respondent } \\
\text { facilitated to be } \\
\text { member of VICOBA } \\
(\%)\end{array}$ & $\begin{array}{c}11 \\
\text { Received training on } \\
\text { women's } \\
\text { empowerment (\%) }\end{array}$ \\
\hline Intervention group mean & 0.44 & 0.51 & 0.45 \\
\hline Comparison group mean & 0.00 & 0.07 & 0.01 \\
\hline Difference: & $0.43^{* * *}$ & $0.44^{* * *}$ & $0.44^{* * *}$ \\
\hline Observations (intervention & $(0.07)$ & $(0.05)$ & 219 \\
\hline group) & 219 & 219 & 654 \\
\hline Observations (total) & 654 & 654 & $0.05)$ \\
\hline
\end{tabular}

Standard errors clustered at village level in parentheses; ${ }^{*} p<0.1,{ }^{* *} p<0.05,{ }^{* * *} p<0.01$; PSM estimates are bootstrapped with 1,000 repetitions.

Other than these direct inputs, large differences exist between the intervention and comparison households in terms of membership of associations and receipt of training on women's empowerment. It is also important to note that comparison households had generally very little exposure to the types of intervention that the project was initiating: for most activities, exposure was close to zero.

Finally, it should be noted that while there was a significant difference between intervention and comparison households in terms of whether technical support (column 2) and agricultural credit (column 3) had been received, the overall proportion of project households receiving such support was relatively small.

\subsection{TRAINING ATTENDED AND AGRICULTURAL PRACTICES ADOPTED}

Figure 5.1 reports the differences between project and comparison households regarding the training in which they participated over the course of the project. The training topics included farm technologies relevant to sunflower cultivation, storage techniques, chicken farming, business planning and women's rights. There are positive and highly significant differences in favour of the project across all the training topics. Participation across all types of training ranged from 1 percent to 5 percent among the comparison households, compared with between 46 percent and 78 percent among the intervention households. 
Figure 5.1: Proportion of comparison and project households who received training

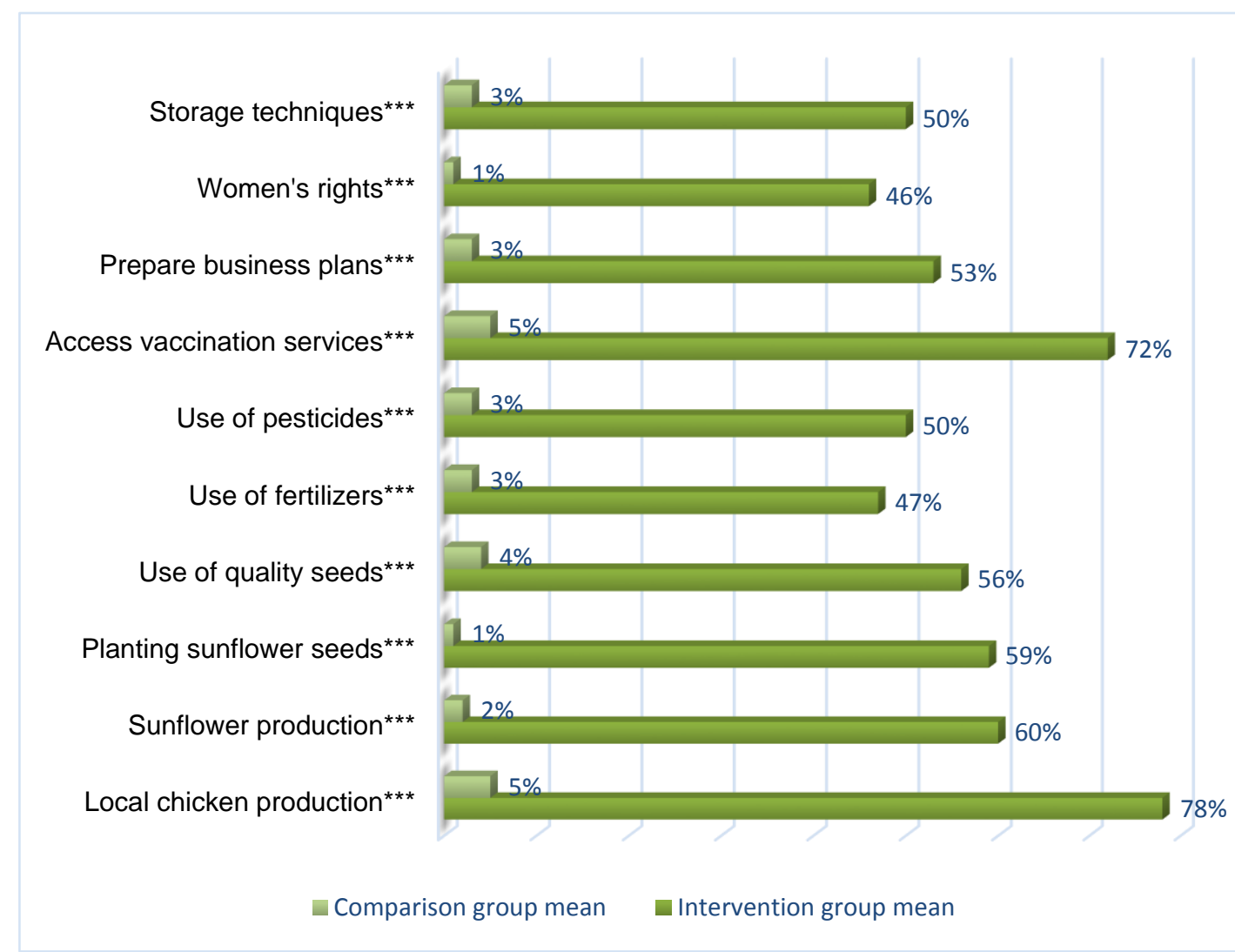

${ }^{*} p<0.1,{ }^{* *} p<0.05,{ }^{* * *} p<0.01$; PSM estimates are bootstrapped with 1,000 repetitions.

The overall differences between intervention and comparison households regarding participation in training and adoption of new techniques are shown in Table 5.2. As is clear from column 1, a much greater proportion of project households reported attending at least one training session related to the different topics shown in Figure 5.1. Similarly, project households reported attending on average almost 15 sessions over the four years of project implementation - compared with almost zero sessions for comparison households.

Households were also asked to self-report whether they had put any of the training they received into practice. While the challenges associated with self-reporting must be noted, 89 percent of project households reported having put at least one of the aspects of training into practice over the four years.

Table 5.2: Training received by households and practices adopted

\begin{tabular}{|c|c|c|c|c|c|}
\hline & 1 & 2 & 3 & 4 & 5 \\
\hline & $\begin{array}{l}\text { Attended } \\
\text { training in } \\
\text { previous } \\
\text { four years } \\
(\%)\end{array}$ & $\begin{array}{l}\text { Number of } \\
\text { times } \\
\text { participants } \\
\text { attended } \\
\text { training }\end{array}$ & $\begin{array}{c}\text { Training } \\
\text { put into } \\
\text { practice } \\
(\%)\end{array}$ & $\begin{array}{l}\text { Number of } \\
\text { trainings } \\
\text { put into } \\
\text { practice }\end{array}$ & $\begin{array}{l}\text { Households } \\
\text { who put more } \\
\text { than one } \\
\text { training into } \\
\text { practice (\%) }\end{array}$ \\
\hline Intervention group mean & 0.91 & 14.63 & 0.89 & 5.72 & 0.82 \\
\hline Comparison group mean & 0.14 & 0.57 & 0.12 & 0.30 & 0.08 \\
\hline \multirow[t]{2}{*}{ Difference: } & $0.78^{\star \star *}$ & $14.05^{\star \star *}$ & $0.78^{\star \star *}$ & $5.41^{\star * *}$ & $0.74^{* * *}$ \\
\hline & $(0.07)$ & $(1.29)$ & $(0.06)$ & $(0.49)$ & $(0.06)$ \\
\hline $\begin{array}{c}\text { Observations } \\
\text { (intervention group) }\end{array}$ & 219 & 219 & 219 & 219 & 219 \\
\hline Observations (total) & 654 & 654 & 654 & 654 & 654 \\
\hline
\end{tabular}


Standard errors clustered at village level in parentheses; ${ }^{*} p<0.1$, ${ }^{* *} p<0.05,{ }^{* * *} p<0.01$; PSM estimates are bootstrapped with 1,000 repetitions.

\subsection{VALUE ADDITION}

The second channel through which the project aimed to increase income and revenues was increasing the value generated by certain agricultural products. The survey investigated value addition by asking whether any agricultural product produced and sold in the previous 12 months had been processed (e.g. milled or ground) before being sold.

Column 1 of Table 5.3 shows the proportion of households reporting that they had processed any of their crops prior to selling, while column 2 presents the number of agricultural products processed. While 44 percent of project households reported processing at least one of their crops prior to selling, there was no significant difference with comparison households, indicating that there is no evidence that the project positively affected value addition.

Table 5.3: Processing of agricultural products

\begin{tabular}{|c|c|c|}
\hline & 1 & 2 \\
\hline & $\begin{array}{l}\text { Households processing } \\
\text { any product (\%) }\end{array}$ & $\begin{array}{c}\text { Number of products } \\
\text { processed }\end{array}$ \\
\hline Intervention group mean & 0.44 & 1.06 \\
\hline Comparison group mean & 0.43 & 1.06 \\
\hline \multirow[t]{2}{*}{ Difference: } & 0.01 & 0.01 \\
\hline & $(0.09)$ & $(0.23)$ \\
\hline Observations (intervention group) & 219 & 219 \\
\hline Observations (total) & 654 & 654 \\
\hline
\end{tabular}

Standard errors clustered at village level in parentheses; ${ }^{*} p<0.1,{ }^{* \star} p<0.05,{ }^{* * *} p<0.01$; PSM estimates are bootstrapped with 1,000 repetitions.

\subsection{ACCESS TO MARKETS}

A third channel through which the project aimed to increase revenues was reducing costs when selling agricultural produce. As part of the project's activities, market centres were constructed within intervention villages where farmers could sell their produce.

Table 5.4 shows that, on average, 68 percent of the intervention households and 41 percent of comparison household sold any crops (column 1). This is a significant difference and it is possible that the project activities - such as market improvements and training - had an impact in increasing the proportion of households selling their crops.

Table 5.4: Transport costs and access to markets

\begin{tabular}{|c|c|c|c|c|}
\hline & $\begin{array}{c}1 \\
\text { Proportion of } \\
\text { farmers selling any } \\
\text { crops (\%) }\end{array}$ & $\begin{array}{c}\text { Selling to local } \\
\text { trader/ } \\
\text { middleman (\%) }\end{array}$ & $\begin{array}{c}\text { Selling to community } \\
\text { association/ } \\
\text { cooperative (\%) }\end{array}$ & $\begin{array}{c}4 \\
\text { Selling to } \\
\text { local market } \\
(\%)\end{array}$ \\
\hline $\begin{array}{c}\text { Intervention group } \\
\text { mean }\end{array}$ & 0.68 & 0.97 & 0.09 & 0.06 \\
\hline $\begin{array}{c}\text { Comparison group } \\
\text { mean }\end{array}$ & 0.41 & 1.00 & 0.00 & 0.00 \\
\hline Difference: & $0.27^{* * *}$ & $-0.03^{* *}$ & $0.09^{* *}$ & $0.06^{* * *}$ \\
\hline $\begin{array}{c}\text { Observations } \\
\text { (intervention group) }\end{array}$ & $(0.10)$ & $(0.01)$ & $(0.04)$ & 149 \\
\hline Observations (total) & 219 & 149 & 149 & 290 \\
\hline
\end{tabular}


Standard errors clustered at village level in parentheses; ${ }^{*} p<0.1,{ }^{* *} p<0.05,{ }^{* * *} p<0.01$; PSM estimates are bootstrapped with 1,000 repetitions.

Of the households who sold any produce, almost all reported selling some of it to local traders or middleman. Among project households, 9 percent reported selling some of their produce to community associations or cooperatives, and 6 percent to local markets. These proportions are significantly greater than among comparison households - and therefore indicate some evidence that the project positively affected these measures. However, at just 9 percent and 6 percent respectively, it is clear that only a small proportion of project households appear to be using local cooperatives or markets as a point of sale for their produce.

Another measure analysed by the review team (not shown in Table 5.4) was to assess any differences between project and comparison households in the reported cost of transporting their goods to market; however, no significant differences were detected. This may be due to the continued domination of 'middlemen' and local traders in capturing local crops from producers, as reported in Table 5.4 .

\subsection{ACCESS TO AGRICULTURAL TECHNOLOGY AND TOOLS}

This section examines how the project influenced households' access to agricultural tools and machinery (e.g. small hand tools, pressing machines, carts, etc.) and modern practices (e.g. organic farming, use of improved certified seeds/seedlings, etc.). The farmers were trained and supported to access these tools and to adopt modern practices, and it was expected that the volume and quality of agricultural production would improve as a result.

Column 1 of Table 5.5 shows that the project households were using a greater number of agricultural tools and machinery, indicating some evidence that the project's activities in this area had led to greater uptake. Figure 5.2 illustrates the differences in the use of various tools and machinery, and shows that some of the largest differences between project and comparison households were in the use of storage facilities and mills. These differences are likely to be linked with the particular emphasis on value addition - including storage and the use of mills - during training sessions.

Table 5.5: Access to agricultural tools and technologies

\begin{tabular}{|c|c|c|c|}
\hline & $\begin{array}{c}1 \\
\text { Average number of } \\
\text { agricultural tools } \\
\text { accessed and used by } \\
\text { households }\end{array}$ & $\begin{array}{l}2 \\
\text { Number of 'modern' } \\
\text { agricultural practices } \\
\text { used by households }\end{array}$ & $\begin{array}{c}3 \\
\text { Proportion of } \\
\text { households who } \\
\text { accessed and used } \\
\text { more than one modern } \\
\text { practice (\%) }\end{array}$ \\
\hline $\begin{array}{l}\text { Intervention group } \\
\text { mean }\end{array}$ & 4.35 & 2.13 & 0.56 \\
\hline $\begin{array}{c}\text { Comparison group } \\
\text { mean }\end{array}$ & 3.56 & 1.41 & 0.31 \\
\hline \multirow[t]{2}{*}{ Difference: } & $0.80^{* \star}$ & $0.71^{* \star \star}$ & $0.25^{\star \star \star}$ \\
\hline & $(0.40)$ & $(0.21)$ & $(0.07)$ \\
\hline $\begin{array}{c}\text { Observations } \\
\text { (intervention group) }\end{array}$ & 219 & 219 & 219 \\
\hline $\begin{array}{c}\text { Intervention group } \\
\text { mean }\end{array}$ & 654 & 654 & 654 \\
\hline
\end{tabular}

Standard errors clustered at village level in parentheses; ${ }^{*} p<0.1,{ }^{* *} p<0.05,{ }^{* * *} p<0.01$; PSM estimates are bootstrapped with 1,000 repetitions.

Tools/agricultural tools refers to agricultural tools used by households: for instance, ploughs/power tillers; warehouse/storage facilities; sharpening materials; rice threshers/corn 
huskers; sieves for grains; rice/corn mills; small hand tools; pressing machines; carts; tractors. Practices/modern agricultural practices refers to practices recommended by the project: for instance, seed nurseries; production of organic concoction/ materials; organic farming; use of improved certified seeds/seedlings; integrated diversified farming systems; farm planning based on weather forecasts.

Figure 5.2: Use of different agricultural tools by comparison and intervention households

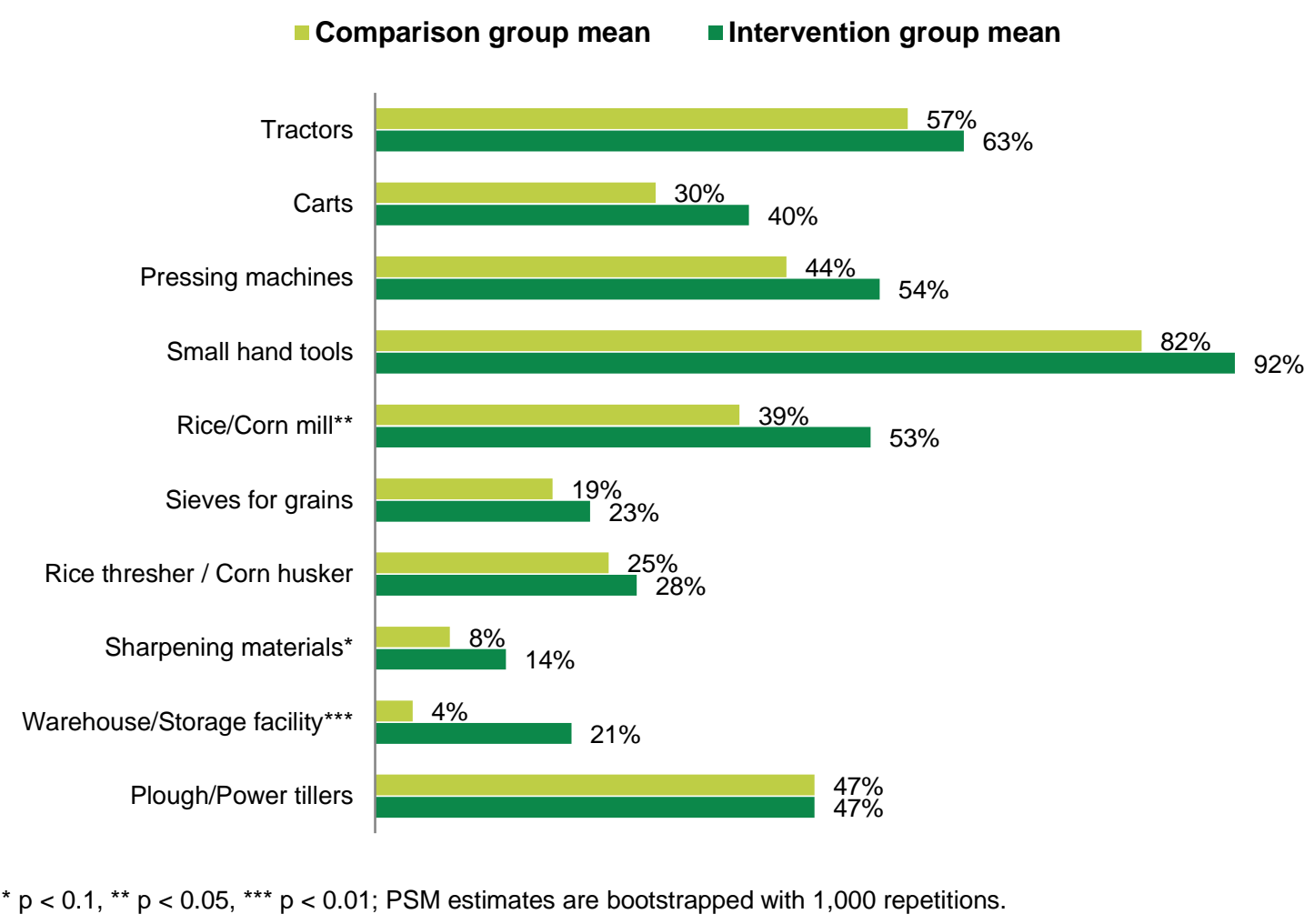

Column 2 in Table 5.5 shows that project households were implementing a greater number of modern agricultural practices, with more than half of project households implementing at least two practices (column 3). Figure 5.3 shows that the most commonly used practice was farm planning based on weather forecasts, but where the project seems to have generated the greatest changes in practice was in the implementation of a diversified farming system and in the use of organic manure and pesticides. There was also some evidence that the project increased the use of improved seeds/seedlings and seed nurseries.

Figure 5.3: Use of different agricultural practices by comparison and intervention households 


\section{Comparison group mean Intervention group mean}

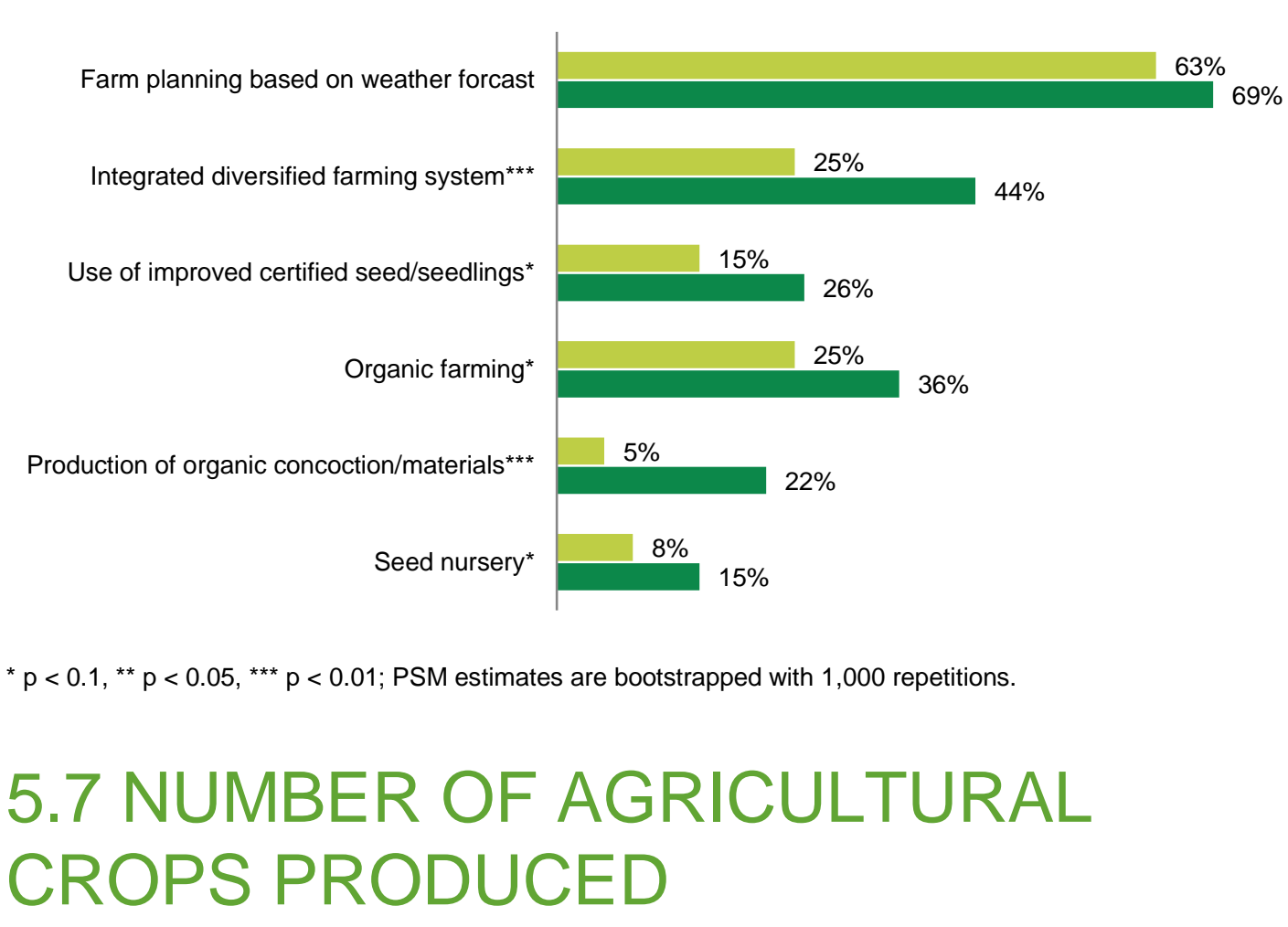

This section considers the project's impact on crop production. As well as encouraging participants to implement improved agricultural practices, the project sought to motivate farmers to diversify their crop portfolio and to use improved techniques for crops such as sunflower, rice, maize, sesame, vegetables, bananas and sweet potatoes. One indication of whether farmers have expanded their crop portfolio is to analyse the differences between the intervention and comparison households in terms of the number of crops being cultivated in the year before the survey.

Table 5.6 presents the average number of crops cultivated by the sampled households (column 1). As is apparent from the table, there is evidence that the project has successfully led to a difference in the number of crops cultivated. Additionally, with no significant difference found between project and comparison households in the number of crops cultivated at baseline (column 2), we can be more confident that it is the project that has effected this change.

\section{Table 5.6: Number of crops produced}

\begin{tabular}{|c|c|c|}
\hline & $\begin{array}{c}1 \\
\text { Number of agricultural crops } \\
\text { produced in the previous 12 } \\
\text { months }\end{array}$ & $\begin{array}{c}\text { Number of crops farmed - } \\
2011\end{array}$ \\
\hline Intervention group mean & 3.05 & 2.87 \\
\hline Comparison group mean & 2.39 & 2.49 \\
\hline Difference: & $0.67^{\star *}$ & 0.38 \\
\hline Observations (intervention group) & $(0.31)$ & $(0.30)$ \\
\hline Observations (total) & 219 & 219 \\
\hline
\end{tabular}

Standard errors clustered at village level in parentheses; ${ }^{*} p<0.1,{ }^{* *} p<0.05,{ }^{* * *} p<0.01$; PSM estimates are bootstrapped with 1,000 repetitions. 


\subsection{SUNFLOWER PRODUCTION, SALES AND REVENUES}

As sunflower cultivation was one of the primary interventions supported by the project, the review sought to discover whether the quantities of sunflower produced and sold, and the revenues obtained by the farmers who participated in the project, were different from those who did not.

Column 1 of Table 5.7 shows that more than two-thirds of project households cultivated sunflower in the 12 months prior to the survey; however, there were no significant differences between project and comparison villages in the overall proportion of households cultivating the crop. Columns $2-5$ present details of the quantities of sunflower produced and sold, and the revenues received from its sale.

For these variables - and for the production/selling variables contained in the following tables - the log analysis is presented. This analysis is more reliable than the raw mean averages, as it reduces the effects of extreme outliers in the data, which are likely to be due to data being estimated by the respondents.

As shown in column 2, among the farmers who cultivated sunflower, there is modest evidence that project households produced a greater quantity of sunflower than their comparators. There is stronger evidence that the project effected an increase in the quantity of sunflower sold by project households (column 3). While there was no difference in the price per kilogram $(\mathrm{kg})$ received by project households (column 4 ), sunflower farmers in the project areas earned slightly higher revenues, due to the greater quantity of sunflower sold (column 5).

Table 5.7: Quantities of sunflower produced and sold, price per $\mathrm{kg}$, and revenues obtained

\begin{tabular}{|c|c|c|c|c|c|}
\hline & $\begin{array}{c}1 \\
\text { Proportion } \\
\text { of } \\
\text { households } \\
\text { who } \\
\text { cultivated } \\
\text { sunflower } \\
(\%)\end{array}$ & $\begin{array}{c}2 \\
\text { Quantity of } \\
\text { sunflower } \\
\text { produced in the } \\
\text { previous } 12 \\
\text { months (logarithm } \\
\text { of } \mathrm{kg} \text { ) }\end{array}$ & $\begin{array}{c}3 \\
\text { Quantity of } \\
\text { sunflower sold } \\
\text { in the previous } \\
12 \text { months } \\
\text { (logarithm of } \\
\text { kg) }\end{array}$ & $\begin{array}{l}4 \\
\text { Price per } \\
\text { kg of } \\
\text { sunflower } \\
\text { (logarithm } \\
\text { of TSh) }\end{array}$ & $\begin{array}{c}5 \\
\text { Revenues } \\
\text { from } \\
\text { sunflower } \\
\text { sales in the } \\
\text { previous } 12 \\
\text { months } \\
\text { (logarithm of } \\
\text { TSh) }\end{array}$ \\
\hline $\begin{array}{l}\text { Intervention } \\
\text { group mean }\end{array}$ & 0.68 & 5.79 & 5.50 & 5.95 & 11.45 \\
\hline $\begin{array}{l}\text { Comparison } \\
\text { group mean }\end{array}$ & 0.59 & 5.46 & 4.94 & 6.18 & 11.13 \\
\hline \multirow[t]{2}{*}{ Difference: } & 0.08 & $0.42^{*}$ & $0.71^{* *}$ & -0.24 & $0.47^{*}$ \\
\hline & $(0.12)$ & $(0.23)$ & $(0.30)$ & $(0.35)$ & $(0.27)$ \\
\hline $\begin{array}{l}\text { Observations } \\
\text { (intervention } \\
\text { group) }\end{array}$ & 219 & 140 & 79 & 79 & 79 \\
\hline $\begin{array}{l}\text { Observations } \\
\text { (total) }\end{array}$ & 654 & 293 & 150 & 149 & 149 \\
\hline
\end{tabular}

Standard errors clustered at village level in parentheses; ${ }^{\star} p<0.1,{ }^{* \star} p<0.05,{ }^{* \star \star} p<0.01$; PSM estimates are bootstrapped with 1,000 repetitions. 


\subsection{EGGS, CHICKS AND CHICKEN PRODUCTION, SALES AND REVENUES}

This section considers the project's impact on chicken farming. The respondents were asked whether any member of the household had been involved in the production of chicken, eggs or chicks in the previous 12 months. If yes, they were asked the total quantity/number of each that the household produced, how much the household had sold in the same period and the total revenue obtained from the sales.

Table 5.8 starts by reporting households' engagement in egg production. Overall, 42 percent of the project households engaged in egg production, compared with 25 percent of comparison households - a significant difference. Of those households producing eggs, project households produced a much greater quantity than comparison households.

Just over 40 percent of the households who produced eggs sold them to others, and project households sold a significantly greater quantity of eggs than their comparators. While the price per egg received by project households was no different from that received by comparison households, the greater quantity sold by project households meant that they earned greater revenue from egg sales. 
Table 5.8: Quantity of eggs produced, sold and revenues obtained

\begin{tabular}{|c|c|c|c|c|c|}
\hline & $\begin{array}{c}1 \\
\text { Proportion } \\
\text { of } \\
\text { households } \\
\text { who } \\
\text { produced } \\
\text { eggs (\%) }\end{array}$ & $\begin{array}{c}2 \\
\text { Quantity of } \\
\text { eggs } \\
\text { produced in } \\
\text { the previous } \\
12 \text { months } \\
\text { (logarithm of } \\
\text { numbers) }\end{array}$ & $\begin{array}{c}3 \\
\text { Quantity of } \\
\text { eggs sold in the } \\
\text { previous } 12 \\
\text { months } \\
\text { (logarithm of } \\
\text { numbers) }\end{array}$ & $\begin{array}{c}4 \\
\text { Selling } \\
\text { price per } \\
\text { egg } \\
\text { (logarithm } \\
\text { of TSh) }\end{array}$ & $\begin{array}{c}5 \\
\text { Revenues } \\
\text { from egg } \\
\text { sales in the } \\
\text { previous } 12 \\
\text { months } \\
\text { (logarithm of } \\
\text { TSh) }\end{array}$ \\
\hline $\begin{array}{l}\text { Intervention } \\
\text { group mean }\end{array}$ & 0.42 & 4.96 & 5.01 & 5.73 & 10.64 \\
\hline $\begin{array}{l}\text { Comparison } \\
\text { group mean }\end{array}$ & 0.25 & 3.78 & 3.56 & 5.62 & 10.02 \\
\hline \multirow[t]{2}{*}{ Difference: } & $0.17^{\star \star \star}$ & $1.25^{\star \star \star}$ & $1.50^{* \star *}$ & 0.10 & $1.09^{\star *}$ \\
\hline & $(0.06)$ & $(0.25)$ & $(0.57)$ & $(0.09)$ & $(0.54)$ \\
\hline $\begin{array}{c}\text { Observations } \\
\text { (intervention } \\
\text { group) }\end{array}$ & 219 & 91 & 41 & 83 & 41 \\
\hline $\begin{array}{l}\text { Observations } \\
\text { (total) }\end{array}$ & 654 & 148 & 60 & 151 & 60 \\
\hline
\end{tabular}

Standard errors clustered at village level in parentheses; ${ }^{*} p<0.1,{ }^{* \star} p<0.05,{ }^{* \star *} p<0.01$; PSM estimates are bootstrapped with 1,000 repetitions.

Table 5.9 considers how the project affected chick production. It first shows whether or not respondents were involved in chick production, and then looks at the quantity/number of chicks produced and sold, the unit price received and total revenues generated.

Almost two-thirds of project households engaged in chick production in the year before the survey, but there was no evidence that the project directly encouraged more households to take up production (column 1). Among those households breeding chicks, the project households produced a significantly greater quantity than comparison households (column 2). Interestingly, the price that project households received per chick was significantly higher than comparison households (column 3), which in turn led to greater revenues from the sale of chicks. These results provide some evidence that the project, while not increasing the proportion of households involved in chick production, positively affected the quality of chicks being produced (as judged by the higher prices received) and therefore the revenues earned.

Table 5.9: Quantities of chicks produced and sold, and revenues obtained

\begin{tabular}{|c|c|c|c|c|}
\hline & $\begin{array}{c}1 \\
\text { Proportion of } \\
\text { households } \\
\text { who produced } \\
\text { chicks (\%) }\end{array}$ & $\begin{array}{c}2 \\
\text { Quantity of } \\
\text { chicks } \\
\text { produced in the } \\
\text { previous } 12 \\
\text { months } \\
\text { (logarithm of } \\
\text { numbers) }\end{array}$ & $\begin{array}{c}3 \\
\text { Selling price per } \\
\text { chick (logarithm } \\
\text { of TSh) }\end{array}$ & $\begin{array}{c}4 \\
\text { Revenues from } \\
\text { sales of chicks } \\
\text { in the previous } \\
12 \text { months } \\
\text { (logarithm of } \\
\text { TSh) }\end{array}$ \\
\hline $\begin{array}{l}\text { Intervention } \\
\text { group mean }\end{array}$ & 0.63 & 3.39 & 7.58 & 10.07 \\
\hline $\begin{array}{l}\text { Comparison } \\
\text { group mean }\end{array}$ & 0.51 & 2.98 & 7.25 & 9.01 \\
\hline \multirow[t]{2}{*}{ Difference: } & 0.12 & $0.42^{* *}$ & $0.34^{* *}$ & $1.32^{* * *}$ \\
\hline & $(0.08)$ & $(0.17)$ & $(0.14)$ & $(0.39)$ \\
\hline $\begin{array}{l}\text { Observations } \\
\text { (intervention } \\
\text { group) }\end{array}$ & 219 & 123 & 47 & 47 \\
\hline $\begin{array}{l}\text { Observations } \\
\text { (total) }\end{array}$ & 654 & 244 & 102 & 102 \\
\hline
\end{tabular}

Standard errors clustered at village level in parentheses; ${ }^{*} p<0.1,{ }^{* \star} p<0.05,{ }^{* \star *} p<0.01$; PSM estimates are bootstrapped with 1,000 repetitions. 
In Table 5.10, column 1 shows that 81 percent of project households were engaged in poultry rearing, which is significantly higher than the matched comparison group, indicating that the project positively encouraged household involvement. Of those households engaged in poultry rearing, column 2 shows that project households produced, on average, more chickens in the 12 months prior to the survey than their comparators. While the average number of chickens sold by project and comparison households was similar (column 3), there is some modest evidence to suggest that slightly greater revenues were earned from sales among project households (column 5).

Table 5.10: Quantity of chicken produced, sold and revenues obtained

\begin{tabular}{|c|c|c|c|c|c|}
\hline & $\begin{array}{c}1 \\
\text { Proportion } \\
\text { of } \\
\text { households } \\
\text { who } \\
\text { produced } \\
\text { chicken (\%) }\end{array}$ & $\begin{array}{c}2 \\
\text { Number of } \\
\text { chickens } \\
\text { produced in the } \\
\text { previous } 12 \\
\text { months } \\
\text { (logarithm of } \\
\text { numbers) }\end{array}$ & $\begin{array}{c}3 \\
\text { Number of } \\
\text { chickens sold in } \\
\text { the previous } 12 \\
\text { months (logarithm } \\
\text { of numbers) }\end{array}$ & $\begin{array}{c}4 \\
\text { Selling } \\
\text { price per } \\
\text { chicken } \\
\text { (logarithm } \\
\text { of TSh) }\end{array}$ & $\begin{array}{c}5 \\
\text { Revenues } \\
\text { from chicken } \\
\text { sales in the } \\
\text { previous } 12 \\
\text { months } \\
\text { (logarithm of } \\
\text { TSh) }\end{array}$ \\
\hline $\begin{array}{l}\text { Intervention } \\
\text { group mean }\end{array}$ & 0.81 & 3.04 & 2.66 & 8.89 & 11.48 \\
\hline $\begin{array}{l}\text { Comparison } \\
\text { group mean }\end{array}$ & 0.63 & 2.53 & 2.41 & 8.76 & 10.92 \\
\hline \multirow[t]{2}{*}{ Difference: } & $0.18^{\star \star \star}$ & $0.48^{* * *}$ & -0.05 & 0.17 & $0.48^{*}$ \\
\hline & $(0.07)$ & $(0.12)$ & $(0.31)$ & $(0.34)$ & $(0.25)$ \\
\hline $\begin{array}{c}\text { Observations } \\
\text { (intervention } \\
\text { group) }\end{array}$ & 219 & 174 & 109 & 132 & 110 \\
\hline $\begin{array}{l}\text { Observations } \\
\text { (total) }\end{array}$ & 654 & 360 & 190 & 265 & 191 \\
\hline
\end{tabular}

Standard errors clustered at village level in parentheses; ${ }^{*} p<0.1,{ }^{* *} p<0.05,{ }^{* \star *} p<0.01$; PSM estimates are bootstrapped with 1,000 repetitions.

Overall, the findings of this section suggest that the project had a greater positive impact on egg and chick production than it did on poultry rearing.

\subsection{TOTAL QUANTITY OF CROPS PRODUCED AND SOLD, AND REVENUES OBTAINED}

Although the project focused primarily on increasing income through sunflower cultivation and chicken farming, the training and capacity building around farm technologies and crop diversification were also expected to bring a positive change in the production of other crops being cultivated by the project participants. This section, therefore, assesses the effect of the project activities on overall crop production and revenue generation.

The questionnaire asked each respondent to indicate whether or not they had produced a particular agricultural product from a list of 10 different crops (sunflower, maize, rice, bananas, vegetables, cassava, cowpea, sweet potato, sesame and coconut) in the previous 12 months. If they responded positively, they were then asked to estimate the total quantity of each crop produced in this period. The results for the average total crop production, sales and revenues are presented in Table 5.11 as the logarithm of the mean.

Of the households who produced any crops, the project households, on average, produced and sold a greater quantity of agricultural produce than comparison households (columns 1 and 2). The differences are moderately significant, indicating some evidence that the project 
had some positive effect on these measures. The evidence is more robust regarding the increased total revenue earned from the sale of crops by project households (column 3).

Table 5.11: Quantity of agricultural production

\begin{tabular}{|c|c|c|c|}
\hline & $\begin{array}{c}\text { Total quantity of } \\
\text { crops produced in } \\
\text { the previous 12 } \\
\text { months (logarithm of } \\
\text { kg) }\end{array}$ & $\begin{array}{c}\text { Total quantity of } \\
\text { crops sold in the } \\
\text { previous 12 months } \\
\text { (logarithm of kg) }\end{array}$ & $\begin{array}{c}\text { Total revenue from } \\
\text { sales of all crops in } \\
\text { the previous 12 } \\
\text { months (logarithms } \\
\text { of TSh }\end{array}$ \\
\hline Intervention group mean & 7.04 & 6.16 & 12.55 \\
\hline Comparison group mean & 6.62 & 5.73 & 12.05 \\
\hline Difference: & $0.45^{\star \star}$ & $0.39^{\star \star}$ & $0.47^{\star \star}$ \\
\hline $\begin{array}{c}\text { Observations (intervention } \\
\text { group) }\end{array}$ & $(0.18)$ & $(0.19)$ & $(0.15)$ \\
\hline Observations (total) & 197 & 147 & 149 \\
\hline
\end{tabular}

Standard errors clustered at village level in parentheses; ${ }^{*} p<0.1$, ${ }^{* *} p<0.05,{ }^{* * *} p<0.01$; PSM estimates are bootstrapped with 1,000 repetitions.

\subsection{OVERALL HOUSEHOLD INCOME}

Measuring household income directly is problematic: self-reported measures of total income are generally regarded as unreliable, given the wide variety of endeavours that such populations engage in to generate income. Most households in this sample were engaged in a range of livelihood activities; a direct income measure would therefore have to collect detailed information about the contribution of each of these activities to household income.

For these reasons, the survey did not attempt to collect data on total household income directly. However, there is a widely recognized and strong association between household income and consumption. This Effectiveness Review therefore followed common practice in micro-level socio-economic analysis by considering household consumption and expenditure as an indicator of income.

To that end, respondents were asked to provide detailed information about their recent expenditure on both food and non-food items. Firstly, they were asked, from a list of 26 products, what types of food they had consumed over the previous seven-day period, and the particular quantities. The quantities of each food item consumed were then converted into a monetary value. This was done by asking the respondent how much was paid for the food item in question or - if the food item was produced by the household itself - how much it would be worth if it was purchased from the local market. The respondents were also asked how much they spent on particular regular non-food items and services from a list of 19 items - such as fuel, toothpaste and transport fares - over the previous four weeks. Finally, they were asked to estimate the value of other occasional types of expenditure that they had incurred over the previous 12 months from a list of 25 items, which included clothes, medical expenses and home repairs.

The household expenditure measure was calculated by converting each of the expenditure types into a per day per capita figure and adding them together. This figure was then divided by a factor representing household size, to generate a per day per person expenditure figure. As with the measures of agricultural sales, the expenditure variable has been expressed on a logarithmic scale, to reduce the influence on the overall result of any households with extreme values for total consumption. The comparison of consumption per adult equivalent per day and total household consumption per adult equivalent per day between supported households and comparison households, after logarithmic transformation, is shown in Table 5.12. 
It can be seen in column 1 that the value of food consumed within the households of project participants was significantly higher than that of comparison households. The difference is highly significant, indicating a high degree of confidence that there is a true difference between the project and comparison households that is not just due to random sampling error. The difference in the logarithmic values of 0.20 implies a difference in food consumption between project and comparison households of 22 percent. Similarly, for total household consumption, as shown in column 2, there is a strong and positive difference in favour of project households, with total consumption estimated to be 21 percent higher among project households.

These findings indicate that there is strong evidence that the project had a positive effect on household income, as measured by average consumption across the sampled households.

Table 5.12: Household consumption

\begin{tabular}{|c|c|c|}
\hline & $\begin{array}{c}1 \\
\text { Food consumption per adult } \\
\text { equivalent per day (logarithm } \\
\text { of TSh) }\end{array}$ & $\begin{array}{c}\text { Total household consumption } \\
\text { per adult equivalent per day } \\
\text { (logarithm of TSh) }\end{array}$ \\
\hline Intervention group mean & 7.38 & 7.98 \\
\hline Comparison group mean & 7.18 & 7.79 \\
\hline Difference: & $0.20^{* \star *}$ & $0.19^{\star \star *}$ \\
\hline Observations (intervention group) & $(0.05)$ & $(0.06)$ \\
\hline Observations (total) & 219 & 219 \\
\hline
\end{tabular}

Standard errors clustered at village level in parentheses; ${ }^{*} p<0.1,{ }^{* *} p<0.05,{ }^{* * *} p<0.01$; PSM estimates are bootstrapped with 1,000 repetitions.

\subsection{HOUSEHOLD ASSET WEALTH}

This section explores the project's impact on households' wealth. Wealth may be interpreted in two ways from the perspective of livelihoods. Firstly, it may be seen as a driver of household income, insofar as households can sell off assets in times of crisis but can also more easily finance the costly investments needed to adapt livelihood strategies and to innovate. However, wealth may also be regarded as exactly the type of well-being indicator - a 'final' outcome that would be improved in livelihoods interventions. Typically, these types of final well-being outcome take more time to change than more immediate drivers or characteristics of livelihoods.

During the course of the questionnaire, respondents were asked to provide information about their household's ownership of various assets (including livestock, productive equipment and household goods), as well as about the conditions of the family's house, both in 2011 and at the time of the survey. This information on asset ownership and housing conditions was used to generate an index of overall household wealth.

The wealth index was generated under the assumption that if each of the assets and housing characteristics constituted suitable indicators of household wealth, they should be correlated with each other. That is, a household that scored favourably on one particular wealth indicator should be more likely to do so for other wealth indicators. A small number of items that had low or negative correlations with the others were therefore not considered to be good wealth indicators and so were excluded from the index.

A data reduction technique called principal component analysis (PCA) was used to produce two indices of overall wealth, one based on the recalled data from the end of 2011, and one based on the household's situation at the time of the survey. In particular, this wealth index is taken directly from the first principal component. PCA enables weights to be assigned to the different assets, to capture as much information as possible from the data. Broadly, PCA 
assigns more weight to those assets that are less correlated with all the other assets, as these carry more information. By contrast, items with more intra-correlation are given less weight.

In order to ensure that the same weights were applied to assets for both the recalled wealth index and the wealth index for the time of the survey, the two 'waves' of data were first pooled before undertaking the PCA procedure. This means that changes in wealth can be more easily compared over time. It should also be noted that the wealth index for 2011 is the measure that has been used throughout this analysis to control for baseline differences in wealth status between project and non-project households.

The analysis in this section begins by 'normalizing' the wealth index. This means that the impacts of the project that are reported can be directly understood as the number of standard deviations by which the project improved wealth. This means that the results from this Effectiveness Review can be more easily compared with other similar evaluations.

Table 5.13 estimates the project's impact on wealth in two ways. Column 1 reports wealth for the project and non-project households at the time of the survey, using the regular matching procedure that has been used throughout the other tables in this review. Column 2, however, takes a slightly different approach. The differences are calculated between wealth at the time of the survey and in 2011, and these differences are compared between project and nonproject households in the matched sample.

Table 5.13: Wealth index

\begin{tabular}{|c|c|c|}
\hline & Normalized wealth index & $\begin{array}{c}\mathbf{2} \\
\text { Intervention group mean }\end{array}$ \\
\hline Comparison group mean & 0.38 & $\begin{array}{c}1 \\
\text { Dence in normalized } \\
\text { wealth index }\end{array}$ \\
\hline Difference: & 0.32 & -0.00 \\
\hline Observations (intervention group) & 0.06 & 0.08 \\
\hline Observations (total) & $(0.15)$ & -0.08 \\
\hline
\end{tabular}

Standard errors clustered at village level in parentheses; ${ }^{*} p<0.1,{ }^{* \star} p<0.05,{ }^{* \star *} p<0.01$; PSM estimates are bootstrapped with 1,000 repetitions.

Although the current wealth index was slightly higher in the project households than the comparison households, the difference is not statistically significant. Similarly, the difference in the wealth index is not significant. Therefore, the data do not provide evidence that the project had a positive impact on household wealth. It should, however, be noted that the increased income among project households evidenced in the previous section may have been utilized for other household needs rather than to acquire more household assets. Also, changes in wealth status may require a longer time horizon in this context to become apparent.

\subsection{GROUP PARTICIPATION AND DECISION MAKING BY WOMEN}

This section considers the project's impact on women's empowerment. In order to investigate this objective, the questionnaire included a section with questions only for women living in the household. These questions were aimed at investigating women's participation in group activities and their influence on decision-making processes at both group and household levels. The groups listed in the questionnaire were:

- women's associations

- farmers' associations/groups

- cooperatives 
- credit or microfinance groups

- disaster management groups

- Social support groups.

For group participation and group decision making, available women in the household were asked whether they regularly participated in meetings of any of the above groups, both at the time of the survey and in 2011 . They were also asked to specify the number of groups they participated in, and the number of groups in which they were involved in a decision-making capacity.

Table 5.14 shows that 74 percent of women in the project households reported regularly attending group meetings, compared with 47 percent of women in comparison households (column 1). Very similar proportions of women reported being involved in any group decision making (column 2).

Column 3 shows that the average number of groups in which women participated was significantly higher among project households, and a similar finding was made for the number of groups in which women respondents were involved in decision-making (column 4).

These results suggest that the project had a positive and statistically significant impact on women's participation in groups and their subsequent involvement in decision making.

Table 5.14: Group participation

\begin{tabular}{|c|c|c|c|c|}
\hline & 1 & 2 & 3 & 4 \\
\hline & $\begin{array}{c}\text { Women } \\
\text { regularly } \\
\text { attending } \\
\text { meetings of any } \\
\text { of the groups } \\
(\%)\end{array}$ & $\begin{array}{l}\text { Involved in } \\
\text { group decision } \\
\text { making (\%) }\end{array}$ & $\begin{array}{c}\text { Number of } \\
\text { groups in which } \\
\text { women } \\
\text { participate }\end{array}$ & $\begin{array}{l}\text { Number of } \\
\text { groups in which } \\
\text { respondents are } \\
\text { involved in } \\
\text { group decision } \\
\text { making }\end{array}$ \\
\hline $\begin{array}{c}\text { Intervention group } \\
\text { mean }\end{array}$ & 0.74 & 0.71 & 2.58 & 2.41 \\
\hline $\begin{array}{c}\text { Comparison group } \\
\text { mean }\end{array}$ & 0.47 & 0.45 & 1.10 & 1.03 \\
\hline \multirow[t]{2}{*}{ Difference: } & $0.27^{\star * \star}$ & $0.26^{\star * \star}$ & $1.47^{\star \star \star}$ & $1.37^{\star \star \star}$ \\
\hline & $(0.07)$ & $(0.07)$ & $(0.30)$ & $(0.29)$ \\
\hline $\begin{array}{l}\text { Observations } \\
\text { (intervention } \\
\text { group) }\end{array}$ & 201 & 201 & 201 & 201 \\
\hline $\begin{array}{l}\text { Observations } \\
\text { (total) }\end{array}$ & 581 & 581 & 581 & 581 \\
\hline
\end{tabular}

Standard errors clustered at village level in parentheses; ${ }^{*} p<0.1,{ }^{\star *} p<0.05,{ }^{* * *} p<0.01$; PSM estimates are bootstrapped with 1,000 repetitions.

The questionnaire also investigated women's influence on decision making at the household level. The key areas of interest for household decision making were:

- keeping and managing household income

- buying and selling productive assets (e.g. land and machines)

- buying and selling livestock

- how much money to invest in business activities

- what food to buy and consume

- how children should be educated

- housework and care of persons

- whether women can travel to visit relatives outside the community

- whether women can participate in community group activities or meetings. 
For each of these areas women were asked who was the decision maker, and if the decision was not made solely by the woman being interviewed (i.e. if the decision was made jointly or individually by other household members), then how much influence she had over the decision-making process.

It is immediately apparent from Table 5.15 how similar the results are for women in both project and comparison households, indicating that there is no evidence - at least from this review - that the project had an impact on women's involvement in household decision making.

Table 5.15: Women's influence over household decision making

\begin{tabular}{|l|c|c|c|} 
& $\begin{array}{c}\text { Women solely } \\
\text { responsible for } \\
\text { household decision } \\
\text { making } \\
\text { (\% of decision- } \\
\text { making areas) }\end{array}$ & $\begin{array}{c}\text { Women have large } \\
\text { influence over } \\
\text { household decision } \\
\text { making } \\
\text { (\% of decision- } \\
\text { making areas) }\end{array}$ & $\begin{array}{c}\text { Women have little/no } \\
\text { influence over } \\
\text { household decision } \\
\text { making } \\
\text { (\% of decision- } \\
\text { making areas) }\end{array}$ \\
\hline Intervention group mean & 0.21 & 0.48 & 0.22 \\
\hline Comparison group mean & 0.20 & 0.50 & 0.24 \\
\hline Difference: & 0.01 & -0.02 & -0.02 \\
\hline & $(0.03)$ & $(0.06)$ & $(0.03)$ \\
\hline $\begin{array}{l}\text { Observations } \\
\text { (intervention group) }\end{array}$ & 201 & 201 & 201 \\
\hline Observations (total) & 581 & 581 & 581 \\
\hline
\end{tabular}

Standard errors clustered at village level in parentheses; ${ }^{*} p<0.1,{ }^{* \star} p<0.05,{ }^{* \star *} p<0.01$; PSM estimates are bootstrapped with 1,000 repetitions. 


\section{6

\subsection{CONCLUSIONS}

The results show clearly that the project households in the survey have significantly higher income and food security - as measured by household consumption - compared with the comparison group. Total consumption and food consumption were estimated to be approximately 21 percent and 22 percent higher among project participants than nonparticipants, providing evidence that the project had a corresponding positive effect on overall household income and food security.

There were also significant positive differences between project and comparison households regarding the average quantities of sunflower, eggs, chicks and chicken produced. Similarly, there is evidence that this has led to increased household revenues - particularly from the sale of eggs and chicks.

There is also evidence that the project effected a change in the diversity of crops cultivated by participating households. On average, the total number of crops cultivated and the quantity of all crops harvested and sold among project households were greater than for comparison households. Similarly, the revenue arising from total sales of agricultural produce was also significantly higher among the project households. Project households also used or adopted a significantly higher number of 'modern' farming practices.

Finally, no evidence was detected of changes in the wealth status of respondents.

\subsection{PROGRAMME LEARNING CONSIDERATIONS}

While the findings of this Effectiveness Review are largely positive, some additional lessons emerge from the results that can be applied to other projects of this type in Tanzania and elsewhere. The Tanzania country team and the project team in particular are encouraged to consider the following:

\section{Investigate the effectiveness of the market construction initiative}

According to the project team, one of the key project interventions was the development of market structures in some of the project villages. However, findings from the review suggest that only a few of the project households interviewed had sold their produce through these markets. The majority of households chose to sell their produce through local traders or middlemen. These results warrant further follow-up with both the project team and project households to examine the reasons for this, and whether there is scope to strengthen this intervention. 


\section{Strengthen the role of the producer organizations and cooperatives connected to the value chains targeted by the project}

One of the project's initiatives was to establish producer organizations - particularly around the main value chains it targeted, namely sunflower, eggs and chicken. However, as with the first consideration, the findings showed that very few households sold their agricultural or livestock produce through these farmer organizations or cooperatives. Further research is required, but there seems to be scope for formalizing the remit of these organizations and examining whether there is potential to utilize the increased number of households involved in the production of these crops and poultry products. With the greater number of households involved in production, there should be a greater role for the associations to play in collective marketing and selling - potentially further boosting the strong results seen in production and revenue earned.

\section{Evaluate options for how to add value in the value chains targeted by the project}

Clearly the project was successful in encouraging greater production in the value chains it targeted. This should offer a key opportunity for the project team to consider how to maximize this increase in production by evaluating options for adding value to the produce. Whether in the sunflower value chain or in the chicken rearing element of the project, there seems to be great potential to increase the value of produce, for example through the introduction of value addition machines, such as sunflower oil extractors.

\section{Review the success of the project and explore opportunities to replicate elements of it}

The results of this review indicate that the project was largely successful in its key objectives of encouraging the implementation of improved agricultural practices, increasing production of sunflower, eggs and chicken and in turn increasing overall household income. There seems to be an opportunity here to review and further understand the reasons for such success, and to evaluate whether there are opportunities to replicate the success of these interventions elsewhere. 


\section{APPENDIX 1: BASELINE STATISTICS BEFORE MATCHING}

Table A1.1: Descriptive statistics before matching

\begin{tabular}{|c|c|c|c|c|}
\hline & $\begin{array}{l}\text { Intervention } \\
\text { mean }\end{array}$ & $\begin{array}{l}\text { Comparison } \\
\text { mean }\end{array}$ & Difference & $\begin{array}{l}\text { Standard } \\
\text { error }\end{array}$ \\
\hline Household size & 6.16 & 4.97 & $1.19^{* * *}$ & 0.18 \\
\hline Number of adults & 3.79 & 2.86 & $0.93^{* * *}$ & 0.12 \\
\hline $\begin{array}{l}\text { Proportion of household members who are } \\
\text { young children (\%) }\end{array}$ & 11.33 & 14.74 & $-3.41^{* \star}$ & 1.25 \\
\hline $\begin{array}{l}\text { Proportion of household members who are } \\
\text { elderly (more than } 60 \text { years old) (\%) }\end{array}$ & 8.37 & 9.26 & -0.90 & 1.67 \\
\hline $\begin{array}{l}\text { Proportion of household members who are } \\
\text { adults (more than } 15 \text { years old) (\%) }\end{array}$ & 64.51 & 61.52 & 2.99 & 1.78 \\
\hline $\begin{array}{l}\text { Proportion of household members who are adult } \\
\text { males (\%) }\end{array}$ & 32.14 & 29.93 & 2.21 & 1.65 \\
\hline $\begin{array}{l}\text { Proportion of household members who are adult } \\
\text { females (\%) }\end{array}$ & 32.37 & 31.59 & 0.78 & 1.47 \\
\hline $\begin{array}{l}\text { Proportion of household members who have } \\
\text { completed primary education (\%) }\end{array}$ & 50.95 & 41.04 & $9.91^{\star \star \star}$ & 2.13 \\
\hline $\begin{array}{l}\text { Proportion of household members who have } \\
\text { completed secondary education (\%) }\end{array}$ & 9.73 & 3.50 & $6.23^{* * \star}$ & 1.02 \\
\hline $\begin{array}{l}\text { Proportion of household members who have } \\
\text { completed university education (\%) }\end{array}$ & 0.78 & 0.09 & $0.69^{* *}$ & 0.23 \\
\hline $\begin{array}{l}\text { Proportion of adult household members who } \\
\text { have completed primary education (\%) }\end{array}$ & 50.00 & 39.57 & $10.43^{* \star *}$ & 2.09 \\
\hline $\begin{array}{l}\text { Proportion of adult household members who } \\
\text { have completed secondary education (\%) }\end{array}$ & 9.73 & 3.50 & $6.23^{\star \star \star}$ & 1.02 \\
\hline $\begin{array}{l}\text { Proportion of adult household members who } \\
\text { have completed university education (\%) }\end{array}$ & 0.78 & 0.09 & $0.69^{* *}$ & 0.23 \\
\hline $\begin{array}{l}\text { Household was in the lowest } 20 \% \text { of the wealth } \\
\text { distribution in } 2011 \text { (\%) }\end{array}$ & 12.66 & 29.91 & $-17.25^{\star \star \star}$ & 3.40 \\
\hline $\begin{array}{l}\text { Household was in the second } 20 \% \text { of the wealth } \\
\text { distribution in } 2011 \text { (\%) }\end{array}$ & 7.86 & 19.66 & $-11.80^{\star \star \star}$ & 2.91 \\
\hline $\begin{array}{l}\text { Household was in the third } 20 \% \text { of the wealth } \\
\text { distribution in } 2011 \text { (\%) }\end{array}$ & 20.52 & 19.87 & 0.65 & 3.24 \\
\hline $\begin{array}{l}\text { Household was in the fourth } 20 \% \text { of the wealth } \\
\text { distribution in } 2011 \text { (\%) }\end{array}$ & 22.71 & 18.59 & 4.12 & 3.22 \\
\hline $\begin{array}{l}\text { Household was in the highest } 20 \% \text { of the wealth } \\
\text { distribution in } 2011(\%)\end{array}$ & 36.24 & 11.97 & $24.28^{* * *}$ & 3.09 \\
\hline Household head is Gogo (\%) & 34.93 & 31.20 & 3.74 & 3.78 \\
\hline Household head is Kaguru (\%) & 0.00 & 0.21 & -0.21 & 0.31 \\
\hline Household head is Sukuma (\%) & 1.31 & 7.69 & $-6.38^{* * *}$ & 1.84 \\
\hline Household head is Luguru (\%) & 3.93 & 6.84 & -2.91 & 1.90 \\
\hline Household head is Maasai (\%) & 3.49 & 5.34 & -1.85 & 1.71 \\
\hline
\end{tabular}




\begin{tabular}{|c|c|c|c|c|}
\hline & $\begin{array}{l}\text { Intervention } \\
\text { mean }\end{array}$ & $\begin{array}{l}\text { Comparison } \\
\text { mean }\end{array}$ & Difference & $\begin{array}{l}\text { Standard } \\
\text { error }\end{array}$ \\
\hline Household head is Mha (\%) & 26.64 & 36.75 & $-10.11^{\star \star}$ & 3.79 \\
\hline $\begin{array}{l}\text { Household members earned income from } \\
\text { farming in } 2011(\%)\end{array}$ & 87.77 & 80.77 & $7.00^{*}$ & 3.02 \\
\hline $\begin{array}{l}\text { Household members earned income from } \\
\text { rearing poultry/livestock in } 2011 \text { (\%) }\end{array}$ & 79.91 & 48.50 & $31.41^{* * *}$ & 3.79 \\
\hline $\begin{array}{l}\text { Household members earned income from casual } \\
\text { labour in } 2011 \text { (\%) }\end{array}$ & 21.83 & 13.25 & $8.59^{* *}$ & 2.95 \\
\hline Main household activity in 2011 was farming (\%) & 89.52 & 89.53 & -0.01 & 2.47 \\
\hline $\begin{array}{l}\text { Main household activity in } 2011 \text { was } \\
\text { poultry/livestock rearing (\%) }\end{array}$ & 4.37 & 5.56 & -1.19 & 1.79 \\
\hline $\begin{array}{l}\text { Main household activity in } 2011 \text { was casual } \\
\text { labour (\%) }\end{array}$ & 0.44 & 1.71 & -1.27 & 0.91 \\
\hline $\begin{array}{l}\text { Number of community groups in which } \\
\text { household participated in } 2011 \text { (\%) }\end{array}$ & 179.91 & 57.91 & $122.01^{* \star \star}$ & 11.60 \\
\hline Observations & 229 & 468 & 697 & \\
\hline
\end{tabular}

The construction of the wealth index is described in section 5.12 (household asset wealth).

Variables dated 2011 are estimates, based on recall data.

${ }^{*} p<0.1,{ }^{* *} p<0.05,{ }^{* *} p<0.01$. 


\section{APPENDIX 2: METHODOLOGY USED FOR PROPENSITY SCORE MATCHING}

The analysis of outcome variables presented in section 5 of this report involved group mean comparisons using propensity score matching (PSM). The basic principle of PSM is to match each participant with a non-participant that was observationally similar at baseline and to obtain the programme treatment effect by averaging the differences in outcomes across the two groups after project completion. Unsurprisingly, there are different approaches to matching, i.e. to determining whether or not a household is observationally 'similar' to another household. For an overview, see Caliendo and Kopeinig (2008). ${ }^{2}$

The following sections describe and test the specific matching procedure followed in this Effectiveness Review.

\section{Estimating propensity scores}

It is extremely hard to find two individuals with exactly the same characteristics, but Rosenbaum and Rubin (1983) demonstrate that it is possible to match individuals using a prior probability for an individual to be in the intervention group, naming this its propensity score. ${ }^{3}$ More specifically, propensity scores are obtained by pooling the units from both the intervention and comparison groups and then using a statistical probability model (e.g. a probit regression) to estimate the probability of them participating in the project, conditional on a set of observed characteristics.

Table A2.1 presents the probit regression results used to estimate the propensity scores in this context. To guarantee that none of the matching variables were affected by the intervention, only variables that were measured at baseline were considered, and only those variables that were unlikely to have been influenced by any anticipation of project participation (Caliendo and Kopeinig, 2008).

Table A2.1: Estimating the propensity score on variables used for matching

\begin{tabular}{|l|c|c|c|}
\hline Covariates & Coefficients & Standard error & P>z \\
\hline hh_size & 0.0326438 & 0.0347855 & 0.348 \\
\hline num_adult & 0.1114736 & 0.0526126 & 0.034 \\
\hline hhh_educ_primary & -0.1272208 & 0.1760063 & 0.470 \\
\hline hhh_educ_sec & 0.3428766 & 0.2194133 & 0.118 \\
\hline ethnic_1 & -0.0793902 & 0.1251757 & 0.526 \\
\hline readwrite_2 & 0.6783558 & 0.1988431 & 0.001 \\
\hline wealth1_2011 & -0.0949821 & 0.1780888 & 0.594 \\
\hline wealth2_2011 & -0.261418 & 0.1961974 & 0.183 \\
\hline wealth4_2011 & 0.0835923 & 0.1662678 & 0.615 \\
\hline wealth5_2011 & 0.3481448 & 0.1689852 & 0.039 \\
\hline timetomarket_bl & 0.0002422 & 0.0008655 & 0.780 \\
\hline agriculturalproduction_bl & 0.004007 & 0.0065354 & 0.540 \\
\hline chicks2011 & 0.7041485 & 0.1156769 & 0.000 \\
\hline crop_selected2011_1 & 0.4763942 & 0.1204872 & 0.000 \\
\hline
\end{tabular}


Table A2.2: Estimating the propensity score on the full set of baseline variables

\begin{tabular}{|c|c|c|c|}
\hline Covariates & Coefficients & Standard error & $P>Z$ \\
\hline hh_size & 0.0538362 & 0.0390408 & 0.168 \\
\hline num_adult & 0.0313072 & 0.057989 & 0.589 \\
\hline hhh_female & 0.3418838 & 0.133365 & 0.010 \\
\hline hhh_age & 0.0114601 & 0.0046783 & 0.014 \\
\hline hhh_educ_primary & -0.064092 & 0.1937016 & 0.741 \\
\hline hhh_educ_sec & 0.3696494 & 0.2617549 & 0.158 \\
\hline hhh_educ_univ & -1.847312 & 1.273756 & 0.147 \\
\hline ethnic_1 & -0.301659 & 0.1538075 & 0.050 \\
\hline religion_1 & 0.2615814 & 0.1465203 & 0.074 \\
\hline readwrite_2 & 0.6729279 & 0.2143273 & 0.002 \\
\hline wealth1_2011 & 0.0575762 & 0.2003051 & 0.774 \\
\hline wealth2_2011 & -0.1964798 & 0.2099576 & 0.349 \\
\hline wealth4_2011 & 0.0522107 & 0.1803371 & 0.772 \\
\hline wealth5_2011 & 0.2214334 & 0.1871803 & 0.237 \\
\hline timetomarket_bl & 0.0003264 & 0.0009642 & 0.735 \\
\hline main_2011 & -0.1607121 & 0.2255486 & 0.476 \\
\hline main_2011_1 & -2.290963 & 2.251787 & 0.309 \\
\hline main_2011_3 & -1.553459 & 1.841869 & 0.399 \\
\hline main_2011_6 & -1.508655 & 1.259669 & 0.231 \\
\hline main_2011_7 & -1.675998 & 1.204881 & 0.164 \\
\hline num_groups2011 & 0.2585492 & 0.0436251 & 0.000 \\
\hline ownedland_bl & 0.0105094 & 0.0064607 & 0.104 \\
\hline agriculturalproduction_bl & 0.0006937 & 0.0090849 & 0.939 \\
\hline crop_selected2011_1 & 0.3841289 & 0.1365009 & 0.005 \\
\hline crop_selected2011_2 & -0.0840546 & 0.1506963 & 0.577 \\
\hline crop_selected2011_3 & 0.1336776 & 0.139508 & 0.338 \\
\hline crop_selected2011_5 & 0.1213253 & 0.1927325 & 0.529 \\
\hline crop_selected2011_6 & -0.251327 & 0.2434226 & 0.302 \\
\hline fertileggs2011 & 0.3986811 & 0.170496 & 0.019 \\
\hline chicks2011 & 0.2466768 & 0.1797101 & 0.170 \\
\hline chicken2011 & 0.4613308 & 0.1737989 & 0.008 \\
\hline
\end{tabular}

\section{Defining the region of common support}

After estimating the propensity scores, the presence of a good common support area needs to be checked. The area of common support is the region where the propensity score distributions of the treatment and comparison groups overlap. The common support assumption ensures that "treatment observations have a comparison observation "nearby" in the propensity score distribution' (Heckman, LaLonde and Smith, 1999). ${ }^{4}$ Since some significant differences were found between the intervention and comparison groups in terms of the baseline and demographic characteristics (as detailed in Section 4.2), some of the households in the intervention group were too different from the comparison group to allow for meaningful comparison. The review team developed a minima and maxima comparison, deleting all observations whose propensity score was smaller than the minimum and larger than the maximum in the opposite group (Caliendo and Kopeinig, 2008). In this particular case, none of the 380 households surveyed in the comparison villages were dropped but seven of the 285 households surveyed in the intervention villages were, because they lay outside the common support area. This means that the estimates of differences in outcome characteristics between the various treatment groups apply only to those intervention households that were not dropped i.e. they do not represent the surveyed population as a whole.

Figure A2.1 illustrates the area of common support and indicates the proportion of households lying on and off the common support area, by treatment group. 


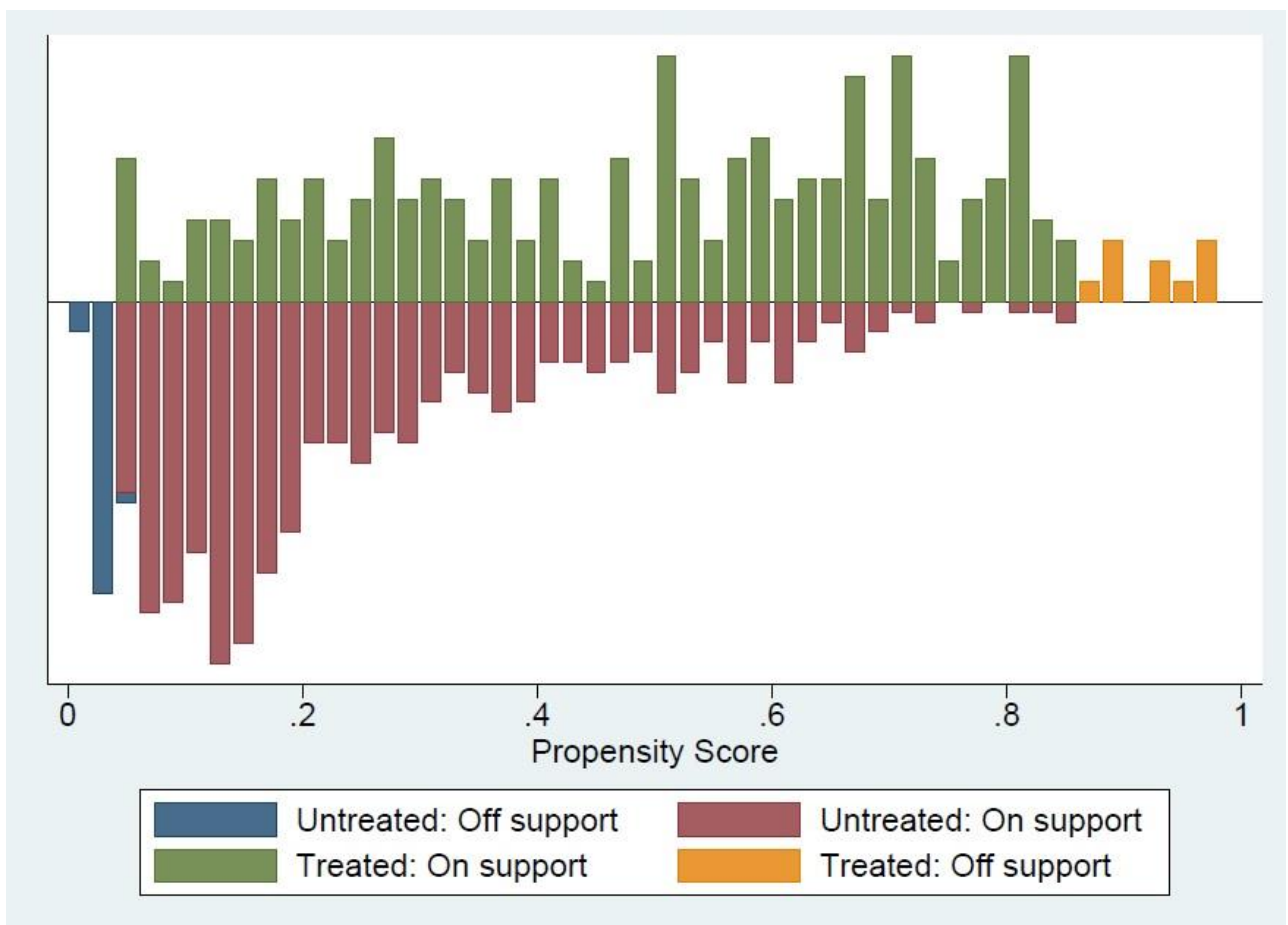

\section{Matching intervention households to comparison households}

Following Rosenbaum and Rubin (1983), after estimating the propensity scores and defining the area of common support, individuals are matched on the basis of their propensity score. The literature has developed a variety of matching procedures. For the main results presented in this Effectiveness Review, the review team chose to employ the method of kernel matching (note that alternative matching procedures are used as robustness checks in Appendix 3). The kernel matching method weights the contribution of each comparison group member, attaching greater weight to those comparison observations that provide a better match with the treatment observations. One common approach is to use the normal distribution with mean zero as a kernel, and weights given by the distribution of the differences in propensity score. Thus 'good' matches get a larger weight than 'poor' matches.

The review team used the psmatch2 module in STATA using 0.06 as a bandwidth and restricted the analysis to the area of common support. When using PSM, standard errors of the estimates were bootstrapped (stratified by community) using 1,000 repetitions to account for the additional variation caused by the estimation of the propensity scores and the determination of the common support. ${ }^{5}$

\section{Check balancing}

For PSM to be valid, the intervention group and the matched comparison group need to be balanced, in that they need to be similar in terms of their observed baseline characteristics. This should be checked. The most straightforward method for doing this is to test whether there are any statistically significant differences in baseline covariates between the intervention and comparison groups in the matched sample. The balance of each of the matching variables after kernel matching is shown in Table A2.3. None of the variables implemented for the matching is statistically significant once the matched sample is used. 
Table A2.3: Balancing test on the set of covariates used for matching

\begin{tabular}{|c|c|c|c|}
\multirow{2}{*}{$\begin{array}{c}\text { Psmatch2 } \\
\text { Treatment assignment }\end{array}$} & Untreated & Treated & Total \\
& 33 & 10 & 43 \\
\hline Off support & 435 & 219 & 654 \\
\hline On support & $\mathbf{4 6 8}$ & $\mathbf{2 2 9}$ & $\mathbf{6 9 7}$ \\
\hline Total & &
\end{tabular}

\begin{tabular}{|c|c|c|c|c|c|c|}
\hline \multirow[t]{2}{*}{ Covariates } & \multirow{2}{*}{$\begin{array}{l}\text { Unmatched } \\
\text { (U) } \\
\text { Matched (M) }\end{array}$} & \multicolumn{2}{|c|}{ Mean } & \multirow{2}{*}{$\begin{array}{c}\% \\
\text { bias }\end{array}$} & \multirow{2}{*}{$\begin{array}{c}\% \\
\text { reduction } \\
\text { bias }\end{array}$} & \multirow{2}{*}{$\begin{array}{c}p- \\
\text { value }\end{array}$} \\
\hline & & Treated & Control & & & \\
\hline \multirow[t]{2}{*}{$h h \_s i z e$} & $\mathbf{U}$ & 5.9041 & 5.108 & 35.7 & & 0.000 \\
\hline & $\mathbf{M}$ & 5.9041 & 5.8787 & 1.1 & 96.8 & 0.905 \\
\hline \multirow[t]{2}{*}{ num_adult } & $\mathbf{U}$ & 3.6164 & 2.9402 & 45.9 & & 0.000 \\
\hline & $\mathbf{M}$ & 3.6164 & 3.6494 & -2.2 & 95.1 & 0.835 \\
\hline \multirow[t]{2}{*}{ hhh_educ_primary } & $\mathbf{U}$ & 0.81279 & 0.66897 & 33.2 & & 0.000 \\
\hline & $\mathbf{M}$ & 0.81279 & 0.80019 & 2.9 & 91.2 & 0.739 \\
\hline \multirow[t]{2}{*}{$h h h \_e d u c \_s e c$} & $\mathbf{U}$ & 0.09589 & 0.04828 & 18.5 & & 0.019 \\
\hline & $\mathbf{M}$ & 0.09589 & 0.08635 & 3.7 & 80 & 0.730 \\
\hline \multirow[t]{2}{*}{ ethnic_1 } & $\mathbf{U}$ & 0.3516 & 0.30805 & 9.3 & & 0.262 \\
\hline & $\mathbf{M}$ & 0.3516 & 0.28679 & 13.8 & -48.8 & 0.146 \\
\hline \multirow[t]{2}{*}{ readwrite_2 } & $\mathbf{U}$ & 0.89954 & 0.73333 & 43.9 & & 0.000 \\
\hline & $\mathbf{M}$ & 0.89954 & 0.89009 & 2.5 & 94.3 & 0.748 \\
\hline \multirow[t]{2}{*}{ wealth1_2011 } & $\mathbf{U}$ & 0.13242 & 0.27586 & -36.1 & & 0.000 \\
\hline & $\mathbf{M}$ & 0.13242 & 0.12739 & 1.3 & 96.5 & 0.876 \\
\hline \multirow[t]{2}{*}{ wealth2_2011 } & $\mathbf{U}$ & 0.08219 & 0.18621 & -30.8 & & 0.000 \\
\hline & $\mathbf{M}$ & 0.08219 & 0.08059 & 0.5 & 98.5 & 0.951 \\
\hline \multirow[t]{2}{*}{ wealth4_2011 } & $\mathbf{U}$ & 0.23744 & 0.2 & 9.1 & & 0.270 \\
\hline & $\mathbf{M}$ & 0.23744 & 0.23334 & 1 & 89 & 0.920 \\
\hline \multirow[t]{2}{*}{ wealth5_2011 } & $\mathbf{U}$ & 0.33333 & 0.12874 & 49.9 & & 0.000 \\
\hline & $\mathbf{M}$ & 0.33333 & 0.3647 & -7.7 & 84.7 & 0.492 \\
\hline \multirow[t]{2}{*}{ timetomarket_bl } & $\mathbf{U}$ & 45.945 & 49.409 & -4.9 & & 0.569 \\
\hline & $\mathbf{M}$ & 45.945 & 46.923 & -1.4 & 71.8 & 0.854 \\
\hline \multirow[t]{2}{*}{ agriculturalproduction_bl } & $\mathbf{U}$ & 5.3721 & 3.2914 & 27 & & 0.001 \\
\hline & $\mathbf{M}$ & 5.3721 & 6.9333 & -20.2 & 25 & 0.241 \\
\hline \multirow[t]{2}{*}{ chicks2011 } & $\mathbf{U}$ & 0.57991 & 0.25287 & 70.2 & & 0.000 \\
\hline & $\mathbf{M}$ & 0.57991 & 0.53932 & 8.7 & 87.6 & 0.393 \\
\hline \multirow[t]{2}{*}{ crop_selected2011_1 } & $\mathbf{U}$ & 0.63014 & 0.36322 & 55.3 & & 0.000 \\
\hline & $\mathbf{M}$ & 0.63014 & 0.64574 & -3.2 & 94.2 & 0.735 \\
\hline Observations & & 219 & 435 & & & \\
\hline
\end{tabular}

\begin{tabular}{|c|c|c|c|c|c|c|c|c|c|}
\hline Sample & Ps $R^{2}$ & $\begin{array}{l}\text { LR- } \\
\text { chi2 }\end{array}$ & p>Chi2 & $\begin{array}{l}\text { Mean } \\
\text { bias }\end{array}$ & $\begin{array}{l}\text { Median } \\
\text { bias }\end{array}$ & B & $\mathbf{R}$ & $\begin{array}{c}\% \\
\text { concern }\end{array}$ & $\%$ bad \\
\hline Unmatched & 0.179 & 149.11 & 0.000 & 33.6 & 34.5 & $108.9^{*}$ & 1.35 & 57 & 14 \\
\hline Matched & 0.010 & 5.9 & 0.969 & 5.0 & 2.7 & 23.0 & 0.52 & 14 & 7 \\
\hline
\end{tabular}

* If $\mathrm{B}>25 \%, \mathrm{R}$ outside $(0.5 ; 2)$.

Table A2.4: Balancing test on the full set of baseline covariates

\begin{tabular}{|c|c|c|c|}
\hline \multirow{2}{*}{$\begin{array}{l}\text { Psmatch2 } \\
\text { Treatment } \\
\text { assignment }\end{array}$} & \multicolumn{2}{|c|}{ Psmatch2 Common support } & Total \\
\hline & Untreated & Treated & \\
\hline Off support & 4 & 33 & 37 \\
\hline On support & 464 & 196 & 660 \\
\hline Total & 468 & 229 & 697 \\
\hline
\end{tabular}




\begin{tabular}{|c|c|c|c|c|c|c|}
\hline \multirow[b]{2}{*}{ Covariates } & \multirow{2}{*}{$\begin{array}{l}\text { Unmatched } \\
\text { (U) } \\
\text { Matched (M) }\end{array}$} & \multicolumn{2}{|c|}{ Mean } & \multirow{2}{*}{$\begin{array}{c}\% \\
\text { bias }\end{array}$} & \multirow{2}{*}{$\begin{array}{l}\% \\
\text { reduction } \\
\text { bias }\end{array}$} & \multirow[t]{2}{*}{$p$-value } \\
\hline & & Treated & Control & & & \\
\hline \multirow[t]{2}{*}{ hh_size } & $\mathbf{U}$ & 5.9133 & 4.9828 & 39.6 & & 0.000 \\
\hline & M & 5.9133 & 5.8176 & 4.1 & 89.7 & 0.686 \\
\hline \multirow[t]{2}{*}{ num_adult } & $\mathbf{U}$ & 3.6071 & 2.8664 & 47.7 & & 0.000 \\
\hline & M & 3.6071 & 3.4563 & 9.7 & 79.6 & 0.381 \\
\hline \multirow[t]{2}{*}{ hhh_female } & $\mathbf{U}$ & 0.60714 & 0.61638 & -1.9 & & 0.824 \\
\hline & M & 0.60714 & 0.56637 & 8.4 & -341.4 & 0.414 \\
\hline \multirow[t]{2}{*}{ hhh_age } & U & 44.954 & 43.353 & 11.1 & & 0.213 \\
\hline & M & 44.954 & 44.371 & 4 & 63.6 & 0.666 \\
\hline \multirow[t]{2}{*}{ hhh_educ_primary } & U & 0.79592 & 0.63578 & 36 & & 0.000 \\
\hline & M & 0.79592 & 0.768 & 6.3 & 82.6 & 0.505 \\
\hline \multirow[t]{2}{*}{ hhh_educ_sec } & U & 0.09694 & 0.04526 & 20.2 & & 0.011 \\
\hline & M & 0.09694 & 0.04516 & 20.2 & -0.2 & 0.046 \\
\hline \multirow[t]{2}{*}{ hhh_educ_univ } & $\mathbf{U}$ & 0.0051 & 0.00216 & 4.9 & & 0.530 \\
\hline & M & 0.0051 & 0.00094 & 6.9 & -41.2 & 0.454 \\
\hline \multirow[t]{2}{*}{ ethnic_1 } & $\mathbf{U}$ & 0.30612 & 0.30819 & -0.4 & & 0.958 \\
\hline & $\mathbf{M}$ & 0.30612 & 0.27163 & 7.5 & -1568.3 & 0.453 \\
\hline \multirow{2}{*}{ religion_1 } & U & 0.72959 & 0.66379 & 14.3 & & 0.097 \\
\hline & M & 0.72959 & 0.67473 & 11.9 & 16.6 & 0.236 \\
\hline \multirow[t]{2}{*}{ readwrite_2 } & $U$ & 0.88776 & 0.6875 & 50.4 & & 0.000 \\
\hline & M & 0.88776 & 0.87587 & 3 & 94.1 & 0.716 \\
\hline \multirow[t]{2}{*}{ wealth1_2011 } & U & 0.14286 & 0.29957 & -38.4 & & 0.000 \\
\hline & M & 0.14286 & 0.15559 & -3.1 & 91.9 & 0.724 \\
\hline \multirow[t]{2}{*}{ wealth2_2011 } & U & 0.09184 & 0.19181 & -28.9 & & 0.001 \\
\hline & M & 0.09184 & 0.08696 & 1.4 & 95.1 & 0.866 \\
\hline wealth4_2011 & $U$ & 0.2449 & 0.1875 & 14 & & 0.095 \\
\hline & M & 0.2449 & 0.27098 & -6.3 & 54.6 & 0.556 \\
\hline wealth5_2011 & $U$ & 0.30612 & 0.12069 & 46.4 & & 0.000 \\
\hline & $\mathbf{M}$ & 0.30612 & 0.28843 & 4.4 & 90.5 & 0.702 \\
\hline timetomarket_bl & $U$ & 47.291 & 48.974 & -2.4 & & 0.787 \\
\hline & M & 47.291 & 40.902 & 9.2 & -279.5 & 0.254 \\
\hline main_2011 & $\mathbf{U}$ & 1.4337 & 1.4353 & -0.1 & & 0.990 \\
\hline & M & 1.4337 & 1.3659 & 4.2 & -3956.8 & 0.649 \\
\hline main_2011_1 & U & 0.90306 & 0.89655 & 2.2 & & 0.801 \\
\hline & M & 0.90306 & 0.91025 & -2.4 & -10.4 & 0.807 \\
\hline main_2011_3 & U & 0.04592 & 0.05603 & -4.6 & & 0.597 \\
\hline & M & 0.04592 & 0.03769 & 3.7 & 18.6 & 0.685 \\
\hline main_2011_6 & $U$ & 0.02551 & 0.0194 & 4.1 & & 0.619 \\
\hline & M & 0.02551 & 0.04273 & -11.6 & -181.6 & 0.349 \\
\hline main_2011_7 & $U$ & 0.0051 & 0.01509 & -10 & & 0.285 \\
\hline & $\mathbf{M}$ & 0.0051 & 0.00398 & 1.1 & 88.7 & 0.869 \\
\hline num groups2011 & $\mathbf{U}$ & 1.3214 & 0.58405 & 54.7 & & 0.000 \\
\hline & M & 1.3214 & 1.4475 & -9.3 & 82.9 & 0.445 \\
\hline ownedland_bl & $\mathbf{U}$ & 6.9694 & 3.7839 & 29.3 & & 0.000 \\
\hline & M & 6.9694 & 7.3573 & -3.6 & 87.8 & 0.787 \\
\hline agriculturalproduction_bl & U & 4.6071 & 3.1471 & 19.7 & & 0.018 \\
\hline & $\mathbf{M}$ & 4.6071 & 4.8349 & -3.1 & 84.4 & 0.817 \\
\hline crop_selected2011_1 & U & 0.58673 & 0.34052 & 50.9 & & 0.000 \\
\hline & $\mathbf{M}$ & 0.58673 & 0.64033 & -11.1 & 78.2 & 0.277 \\
\hline crop_selected2011_2 & $U$ & 0.79592 & 0.67026 & 28.6 & & 0.001 \\
\hline & $\mathbf{M}$ & 0.79592 & 0.82365 & -6.3 & 77.9 & 0.486 \\
\hline crop_selected2011_3 & U & 0.36224 & 0.27586 & 18.6 & & 0.027 \\
\hline & M & 0.36224 & 0.41136 & -10.6 & 43.1 & 0.319 \\
\hline crop_selected2011_5 & U & 0.15816 & 0.07543 & 25.9 & & 0.001 \\
\hline & M & 0.15816 & 0.19291 & -10.9 & 58.0 & 0.367 \\
\hline
\end{tabular}




\begin{tabular}{|c|c|c|c|c|c|c|}
\hline crop_selected2011_6 & U & 0.09184 & 0.04957 & 16.5 & & 0.040 \\
\hline & $\mathbf{M}$ & 0.09184 & 0.06945 & 8.7 & 47.0 & 0.417 \\
\hline fertileggs2011 & $\mathbf{U}$ & 0.39286 & 0.11853 & 66.1 & & 0.000 \\
\hline & $\mathbf{M}$ & 0.39286 & 0.39802 & -1.2 & 98.1 & 0.917 \\
\hline chicks2011 & $\mathbf{U}$ & 0.54592 & 0.23707 & 66.6 & & 0.000 \\
\hline & $\mathbf{M}$ & 0.54592 & 0.53134 & 3.1 & 95.3 & 0.773 \\
\hline chicken2011 & $\mathbf{U}$ & 0.72449 & 0.34698 & 81.6 & & 0.000 \\
\hline & $\mathbf{M}$ & 0.72449 & 0.70207 & 4.8 & 94.1 & 0.625 \\
\hline Observations & & $\mathbf{1 9 6}$ & $\mathbf{4 6 4}$ & & & \\
\hline
\end{tabular}

\begin{tabular}{|c|c|c|c|c|c|c|c|c|c|}
\hline Sample & Ps $R^{2}$ & $\begin{array}{l}\text { LR- } \\
\text { chi2 }\end{array}$ & p>Chi2 & $\begin{array}{c}\text { Mean } \\
\text { bias }\end{array}$ & $\begin{array}{l}\text { Median } \\
\text { bias }\end{array}$ & B & R & $\begin{array}{c}\% \\
\text { concern }\end{array}$ & $\%$ bad \\
\hline Unmatched & 0.247 & 198.47 & 0.000 & 27 & 20.2 & $132.1^{*}$ & 1.26 & 55 & 16 \\
\hline Matched & 0.033 & 18.19 & 0.967 & 6.5 & 6.3 & $43.0^{*}$ & 1.53 & 29 & 6 \\
\hline
\end{tabular}

* If $B>25 \%, R$ outside $(0.5 ; 2)$. 
In order to address the validity of the results presented in section 5, additional analyses with different estimation techniques were performed. This section presents the different econometric models used to test the robustness of the estimates presented in section 5 .

\section{Multivariate regression}

The first basic specification for estimating the impact of project participation is an ordinary least squares (OLS) model (when the dependent is continuous) or probit model when the dependent is binary.

$$
Y_{i}=\alpha+\beta_{1} \text { Project participation }_{i}+\delta^{\prime} X_{i}+\varepsilon_{i}
$$

Where $Y_{i}$ is the dependent variable; $X_{i}$ is a vector of household characteristics also employed in the non-parsimonious model in Table A1.1; finally the variable of interest is the dummy variable Project Participation that assumes a value equal to 1 when the household is enrolled in the project, 0 otherwise. When the dependent variable $Y_{i}$ is not continuous but binary, the analysis implemented probit models rather than linear probability models estimated using OLS. It is important to note that in the absence of randomized allocation of the project among the population in the sample, OLS and probit models fail to identify the causal effect of the programme, and can only be used as an additional check for the estimates. In the tables following only $\beta_{1}$ is reported.

\section{Propensity score matching - nearest neighbour}

With nearest neighbour matching, an individual from the comparison group is chosen as a matching partner for a treated individual that is closest in terms of propensity score. Treated individuals can be matched also with $n$ nearest neighbours. The matching can be 'with replacement' when an untreated individual can be used more than once, or 'without replacement' when it can be used only once. Allowing replacement, the average quality of the matching increases and the bias decreases, which is particularly useful when the distribution of the propensity score is very different between project participants and the control group (Caliendo and Kopeinig, 2008). Estimates in the analysis allow matching with five nearest neighbours with replacement.

\section{Propensity score weighting}

Following the example of Hirano and Imbens (2001), ${ }^{6}$ the review team implemented a regression adjustment with weights based on the propensity score. The average treatment effect can be estimated with a parametric framework:

$$
Y_{i}=\alpha+\beta_{1} \text { Project participation }_{i}+\delta_{2}^{\prime} Z_{i}+\delta_{1}^{\prime} X_{i}+\varepsilon_{i}
$$

Where $Y_{i}$ represents the outcome of interest; Project participation $n_{i}$ is a dummy variable equal to 1 if an individual/household is enrolled onto the programme; $X_{\mathrm{i}}$ is a vector of matching covariates that was used to estimate the propensity score match; finally, $Z_{\mathrm{i}}$ is a vector of control variables, which cannot be used for the matching as it is not supposed to influence project participation. The regression is estimated with weights equal to 1 for the treated units and $\hat{\mathrm{e}}(\mathrm{x}) /(1-\hat{\mathrm{e}}(\mathrm{x}))$ for control units.

This parametric regression analysis framework has the advantage of exploring heterogeneity in the treatment effect. Moreover, it allows for controlling of the variables that it is not possible to include in the propensity score equation. 
In the tables following, only $\beta_{1}$ is reported.

Table A3.1: Total crop cultivation in the previous 12 months (quantity produced and sold, and revenue generated)

\begin{tabular}{|c|c|c|c|}
\hline & $\begin{array}{c}1 \\
\text { Total quantity of } \\
\text { crops produced in } \\
\text { the previous } 12 \\
\text { months (logarithm of } \\
\text { kg) }\end{array}$ & $\begin{array}{l}2 \\
\text { Total quantity of } \\
\text { crops sold in the } \\
\text { previous } 12 \text { months } \\
\text { (logarithm of } \mathrm{kg} \text { ) }\end{array}$ & $\begin{array}{c}3 \\
\text { Total revenue from } \\
\text { sales of all crops in } \\
\text { the previous } 12 \\
\text { months (logarithms } \\
\text { of TSh }\end{array}$ \\
\hline \multirow[t]{2}{*}{ OLS regression } & $0.52^{* \star *}$ & $0.53^{* \star}$ & $0.60^{\star *}$ \\
\hline & $(0.15)$ & $(0.18)$ & $(0.19)$ \\
\hline$N$ & 567 & 301 & 302 \\
\hline \multirow[t]{2}{*}{$\begin{array}{l}\text { OLS regression with } \\
\text { alternative matching } \\
\text { variables }\end{array}$} & $0.51^{\star \star \star}$ & $0.57^{* \star *}$ & $0.59^{* * *}$ \\
\hline & $(0.16)$ & $(0.20)$ & $(0.19)$ \\
\hline$N$ & 567 & 301 & 302 \\
\hline \multirow[t]{2}{*}{ OLS with PS weighting } & $0.52^{\star * \star}$ & $0.45^{\star *}$ & $0.55^{\star * \star}$ \\
\hline & $(0.15)$ & $(0.20)$ & $(0.20)$ \\
\hline$N$ & 537 & 289 & 290 \\
\hline \multirow[t]{2}{*}{ Nearest neighbour } & 0.40 & $0.42^{*}$ & $0.37^{*}$ \\
\hline & $(0.29)$ & $(0.25)$ & $(0.20)$ \\
\hline$N$ & 537 & 289 & 290 \\
\hline
\end{tabular}

Robust standard errors in parentheses. PSM estimates are bootstrapped with 1,000 repetitions.

${ }^{*} \mathrm{p}<0.1,{ }^{* *} \mathrm{p}<0.05,{ }^{* * *} \mathrm{p}<0.01$.

Table A3.2: Sunflower cultivation in the previous 12 months (quantities produced and sold, and revenue generated)

\begin{tabular}{|c|c|c|c|c|c|}
\hline & $\begin{array}{c}1 \\
\text { Proportion } \\
\text { of } \\
\text { households } \\
\text { who } \\
\text { cultivated } \\
\text { the crop (\%) }\end{array}$ & $\begin{array}{c}2 \\
\text { Quantity of } \\
\text { sunflower } \\
\text { produced in } \\
\text { the previous } \\
12 \text { months } \\
\text { (logarithm of } \\
\text { kg) }\end{array}$ & $\begin{array}{c}3 \\
\text { Quantity of } \\
\text { sunflower } \\
\text { sold in the } \\
\text { previous } 12 \\
\text { months } \\
\text { (logarithm of } \\
\text { kg) }\end{array}$ & $\begin{array}{c}4 \\
\text { Price per } \\
\text { kg of } \\
\text { sunflower } \\
\text { (logarithm } \\
\text { of TSh) }\end{array}$ & $\begin{array}{c}5 \\
\text { Revenues } \\
\text { from } \\
\text { sunflower } \\
\text { sales in the } \\
\text { previous } 12 \\
\text { months } \\
\text { (logarithm of } \\
\text { TSh) }\end{array}$ \\
\hline \multirow[t]{2}{*}{ OLS regression } & $0.10^{\star \star}$ & $0.42^{* *}$ & $0.39^{*}$ & -0.09 & 0.29 \\
\hline & $(0.03)$ & $(0.16)$ & $(0.19)$ & $(0.22)$ & $(0.23)$ \\
\hline$N$ & 697 & 305 & 154 & 153 & 153 \\
\hline \multirow{2}{*}{$\begin{array}{l}\text { OLS regression } \\
\text { with alternative } \\
\text { matching variables }\end{array}$} & $0.10^{\star * \star}$ & $0.40^{* *}$ & $0.45^{\star \star}$ & -0.13 & 0.32 \\
\hline & $(0.03)$ & $(0.17)$ & $(0.22)$ & $(0.24)$ & $(0.24)$ \\
\hline$N$ & 697 & 305 & 154 & 153 & 153 \\
\hline \multirow{2}{*}{$\begin{array}{l}\text { OLS with PS } \\
\text { weighting }\end{array}$} & $0.09^{* * *}$ & $0.45^{\star *}$ & $0.52^{* * *}$ & -0.15 & 0.36 \\
\hline & $(0.03)$ & $(0.18)$ & $(0.19)$ & $(0.21)$ & $(0.23)$ \\
\hline$N$ & 654 & 293 & 150 & 149 & 149 \\
\hline \multirow[t]{2}{*}{ Nearest neighbour } & $0.10^{*}$ & 0.31 & $0.76^{* *}$ & -0.27 & $0.49^{*}$ \\
\hline & $(0.05)$ & $(0.24)$ & $(0.33)$ & $(0.24)$ & $(0.29)$ \\
\hline$N$ & 654 & 293 & 150 & 149 & 149 \\
\hline
\end{tabular}

Robust standard errors in parentheses. PSM estimates are bootstrapped with 1,000 repetitions.

${ }^{*} p<0.1,{ }^{* *} p<0.05,{ }^{* * *} p<0.01$. 
Table A3.3: Egg production in the previous 12 months (quantities produced and sold, and revenue generated)

\begin{tabular}{|c|c|c|c|c|c|}
\hline & $\begin{array}{c}1 \\
\text { Proportion of } \\
\text { households } \\
\text { who } \\
\text { produced } \\
\text { eggs (\%) }\end{array}$ & $\begin{array}{c}2 \\
\text { Quantity of } \\
\text { eggs produced } \\
\text { in the previous } \\
12 \text { months } \\
\text { (logarithm of } \\
\text { numbers) }\end{array}$ & $\begin{array}{c}3 \\
\text { Quantity of } \\
\text { eggs sold in } \\
\text { the previous } 12 \\
\text { months } \\
\text { (logarithm of } \\
\text { numbers) }\end{array}$ & $\begin{array}{c}4 \\
\text { Selling } \\
\text { price per } \\
\text { egg } \\
\text { (logarith } \\
\text { mof } \\
\text { TSh) }\end{array}$ & $\begin{array}{c}5 \\
\text { Revenues } \\
\text { from egg } \\
\text { sales in the } \\
\text { previous } 12 \\
\text { months } \\
\text { (logarithm of } \\
\text { TSh) }\end{array}$ \\
\hline \multirow[t]{2}{*}{ OLS regression } & $0.14^{\star \star *}$ & $1.09^{\star \star \star}$ & $1.91^{\star \star}$ & 0.18 & $1.25^{\star}$ \\
\hline & $(0.04)$ & $(0.31)$ & $(0.64)$ & $(0.11)$ & $(0.53)$ \\
\hline$N$ & 697 & 156 & 66 & 165 & 65 \\
\hline \multirow{2}{*}{$\begin{array}{l}\text { OLS regression } \\
\text { with alternative } \\
\text { matching variables }\end{array}$} & $0.07^{* \star}$ & $1.02^{\star \star \star}$ & $1.91^{\star \star \star}$ & 0.15 & $1.20^{*}$ \\
\hline & $(0.03)$ & $(0.30)$ & $(0.71)$ & $(0.11)$ & $(0.62)$ \\
\hline$N$ & 697 & 156 & 66 & 165 & 65 \\
\hline \multirow{2}{*}{$\begin{array}{l}\text { OLS with PS } \\
\text { weighting }\end{array}$} & $0.16^{\star * *}$ & $1.01^{\star \star \star}$ & $1.54^{\star \star \star}$ & $0.19^{*}$ & 0.77 \\
\hline & $(0.05)$ & $(0.26)$ & $(0.57)$ & $(0.11)$ & $(0.50)$ \\
\hline$N$ & 654 & 148 & 60 & 151 & 60 \\
\hline \multirow[t]{2}{*}{ Nearest neighbour } & $0.19^{* \star}$ & $1.25^{\star \star \star}$ & $1.51^{\star \star \star}$ & 0.11 & $1.02^{*}$ \\
\hline & $(0.07)$ & $(0.29)$ & $(0.51)$ & $(0.09)$ & $(0.61)$ \\
\hline$N$ & 654 & 148 & 60 & 151 & 60 \\
\hline
\end{tabular}

Robust standard errors in parentheses. PSM estimates are bootstrapped with 1,000 repetitions.

${ }^{*} p<0.1,{ }^{* *} p<0.05,{ }^{* * *} p<0.01$.

Table A3.4: Chick production in the previous 12 months (quantities produced and sold, and revenue generated)

\begin{tabular}{|c|c|c|c|c|}
\hline & 1 & 2 & 3 & 4 \\
\hline & $\begin{array}{c}\text { Proportion of } \\
\text { households } \\
\text { who } \\
\text { produced } \\
\text { chicks (\%) }\end{array}$ & $\begin{array}{l}\text { Quantity of } \\
\text { chicks } \\
\text { produced in } \\
\text { the previous } \\
12 \text { months } \\
\text { (logarithm of } \\
\text { numbers) }\end{array}$ & $\begin{array}{l}\text { Selling price } \\
\text { per chick } \\
\text { (logarithms of } \\
\text { TSh) }\end{array}$ & $\begin{array}{l}\text { Revenues from } \\
\text { sale of chicks } \\
\text { in the previous } \\
12 \text { months } \\
\text { (logarithm of } \\
\text { TSh) }\end{array}$ \\
\hline \multirow[t]{2}{*}{ OLS regression } & $0.09^{* *}$ & $0.52^{* \star *}$ & $0.35^{*}$ & 0.09 \\
\hline & $(0.03)$ & $(0.16)$ & $(0.18)$ & (1.13) \\
\hline$N$ & 697 & 251 & 109 & 23 \\
\hline \multirow{2}{*}{$\begin{array}{l}\text { OLS regression } \\
\text { with alternative } \\
\text { matching variables }\end{array}$} & $0.09^{\star * *}$ & $0.47^{* * *}$ & $0.38^{*}$ & 0.13 \\
\hline & $(0.03)$ & $(0.15)$ & $(0.22)$ & $(1.82)$ \\
\hline$N$ & 697 & 251 & 109 & 109 \\
\hline \multirow{2}{*}{$\begin{array}{l}\text { OLS with PS } \\
\text { weighting }\end{array}$} & $0.09^{* \star}$ & $0.48^{\star * *}$ & $0.29^{* \star}$ & 0.12 \\
\hline & $(0.04)$ & $(0.16)$ & $(0.13)$ & $(1.06)$ \\
\hline$N$ & 654 & 244 & 102 & 102 \\
\hline \multirow[t]{2}{*}{ Nearest neighbour } & 0.09 & $0.48^{* *}$ & 0.25 & 1.12 \\
\hline & $(0.07)$ & $(0.22)$ & $(0.23)$ & $(0.84)$ \\
\hline$N$ & 654 & 244 & 102 & 23 \\
\hline
\end{tabular}

Robust standard errors in parentheses. PSM estimates are bootstrapped with 1,000 repetitions.

${ }^{*} p<0.1,{ }^{* *} p<0.05,{ }^{* * *} p<0.01$. 
Table A3.5: Chicken rearing in the previous 12 months (quantities produced and sold, and revenue generated)

\begin{tabular}{|c|c|c|c|c|c|}
\hline & $\begin{array}{c}1 \\
\text { Proportion of } \\
\text { households } \\
\text { who } \\
\text { produced } \\
\text { chicken (\%) }\end{array}$ & $\begin{array}{l}2 \\
\text { Number of } \\
\text { chickens } \\
\text { produced in } \\
\text { the previous } \\
12 \text { months } \\
\text { (logarithm) }\end{array}$ & $\begin{array}{c}3 \\
\text { Number of } \\
\text { chicken sold in } \\
\text { the previous } 12 \\
\text { months } \\
\text { (logarithm) }\end{array}$ & $\begin{array}{l}4 \\
\text { Selling } \\
\text { price per } \\
\text { chicken } \\
\text { (logarithm } \\
\text { of TSh) }\end{array}$ & $\begin{array}{c}5 \\
\text { Revenues } \\
\text { from chicken } \\
\text { sales in the } \\
\text { previous } 12 \\
\text { months } \\
\text { (logarithm of } \\
\text { TSh) }\end{array}$ \\
\hline \multirow[t]{2}{*}{ OLS regression } & $0.16^{\star \star \star}$ & $0.51^{\star \star \star}$ & 0.36 & 0.12 & $0.62^{* *}$ \\
\hline & $(0.04)$ & $(0.13)$ & $(0.26)$ & $(0.13)$ & $(0.20)$ \\
\hline$N$ & 697 & 371 & 197 & 280 & 198 \\
\hline \multirow[t]{2}{*}{$\begin{array}{l}\text { OLS regression } \\
\text { with alternative } \\
\text { matching variables }\end{array}$} & $0.11^{* * *}$ & $0.46^{\star * *}$ & 0.32 & 0.12 & $0.56^{\star \star \star}$ \\
\hline & $(0.03)$ & $(0.13)$ & $(0.26)$ & $(0.13)$ & $(0.20)$ \\
\hline$N$ & 697 & 371 & 197 & 280 & 198 \\
\hline \multirow[t]{2}{*}{$\begin{array}{l}\text { OLS with PS } \\
\text { weighting }\end{array}$} & $0.16^{\star * \star}$ & $0.53^{\star * \star}$ & 0.27 & 0.17 & $0.67^{\star * \star}$ \\
\hline & $(0.04)$ & $(0.13)$ & $(0.34)$ & $(0.20)$ & $(0.22)$ \\
\hline$N$ & 654 & 360 & 190 & 265 & 191 \\
\hline \multirow[t]{2}{*}{ Nearest neighbour } & $0.21^{\star * *}$ & $0.50^{\star * *}$ & -0.02 & -0.11 & $0.51^{* *}$ \\
\hline & $(0.07)$ & $(0.16)$ & $(0.43)$ & $(0.32)$ & $(0.25)$ \\
\hline$N$ & 654 & 360 & 190 & 265 & 191 \\
\hline
\end{tabular}

Robust standard errors in parentheses. PSM estimates are bootstrapped with 1,000 repetitions.

${ }^{*} p<0.1,{ }^{* *} p<0.05,{ }^{* * *} p<0.01$.

Table A3.6: Wealth index

\begin{tabular}{|l|c|c|}
\multicolumn{1}{|c|}{} & $\begin{array}{c}1 \\
\text { Normalized } \\
\text { wealth index }\end{array}$ & $\begin{array}{c}\text { 2 } \\
\text { Difference in } \\
\text { normalized wealth } \\
\text { index }\end{array}$ \\
\hline OLS regression & 0.08 & -0.03 \\
\hline$N$ & $(0.07)$ & $(0.06)$ \\
\hline OLS regression with alternative matching variables & 697 & 697 \\
\hline & 0.09 & -0.02 \\
\hline$N$ & $(0.07)$ & $(0.06)$ \\
\hline OLS with PS weighting & 697 & 697 \\
\hline & 0.08 & -0.10 \\
\hline$N$ & $(0.12)$ & $(0.11)$ \\
\hline Nearest neighbour & 654 & 654 \\
\hline & -0.03 & -0.19 \\
\hline$N$ & $(0.20)$ & $(0.18)$ \\
\hline
\end{tabular}

Robust standard errors in parentheses. PSM estimates are bootstrapped with 1,000 repetitions.

${ }^{*} p<0.1,{ }^{* *} p<0.05,{ }^{* * *} p<0.01$. 
Table A3.7: Food consumption and Income (total household consumption)

\begin{tabular}{|l|c|c|}
\hline OLS regression & $\begin{array}{c}1 \\
\text { Food consumption per } \\
\text { adult equivalent per day } \\
\text { (logarithm of TSh) }\end{array}$ & $\begin{array}{c}2 \\
\text { Total household consumption } \\
\text { per adult equivalent per day } \\
\text { (logarithm of TSh) }\end{array}$ \\
\hline$N$ & $0.17^{* *}$ & $0.22^{* * *}$ \\
\hline $\begin{array}{l}\text { OLS regression with alternative } \\
\text { matching variables }\end{array}$ & $(0.06)$ & $(0.06)$ \\
\hline N & 696 & 696 \\
\hline OLS with PS weighting & $0.16^{* * *}$ & $0.21^{* \star *}$ \\
\hline & $(0.06)$ & $(0.06)$ \\
\hline$N$ & 696 & 696 \\
\hline Nearest neighbour & $0.20^{* * *}$ & $0.20^{* * *}$ \\
\hline & $(0.06)$ & $(0.06)$ \\
\hline$N$ & 654 & 654 \\
\hline
\end{tabular}

Robust standard errors in parentheses. PSM estimates are bootstrapped with 1,000 repetitions.

${ }^{*} p<0.1,{ }^{* *} p<0.05,{ }^{* * *} p<0.01$. 


\section{NOTES}

$1 \mathrm{~A}$ mature project has been running for long enough - typically at least 2.5 years - to have a reasonable expectation of impact, with either an expenditure rate of at least 70 percent or completion of most of the project activities.

2 M. Caliendo and S. Kopeinig (2008). Some Practical Guidance for the Implementation of Propensity Score Matching. Journal of Economic Surveys, Wiley Blackwell, vol. 22(1), pp.31-72.

3 P.R. Rosenbaum and D.B. Rubin (1983). The Central Role of the Propensity Score in Observational Studies for Causal Effects. Biometrika 70(1), 41-55.

4 J.J. Heckman, R.J. LaLonde and J.A. Smith (1999). The Economics and Econometrics of Active Labor Market Programs, Handbook of Labor Economics, 3(A), 1865-2097.

5 Bootstrapping is a statistical procedure where repeated samples are drawn from the original sample and parameters, such as standard errors, are re-estimated for each draw. The bootstrapped parameter is calculated as the average estimate over the total number of repeated draws.

6 K. Hirano and G.W. Imbens (2001). Estimation of Causal Effects Using Propensity Score Weighting: An Application to Data on Right Heart Catheterization. Health Services \& Outcomes Research Methodology, vol. 2, pp.259-278. 


\section{Oxfam Effectiveness Reviews}

For more information, or to comment on this report, email policyandpractice@oxfam.org.uk

(C) Oxfam GB October 2017

This publication is copyright but the text may be used free of charge for the purposes of advocacy, campaigning, education, and research, provided that the source is acknowledged in full. The copyright holder requests that all such use be registered with them for impact assessment purposes. For copying in any other circumstances, or for re-use in other publications, or for translation or adaptation, permission must be secured and a fee may be charged. Email policyandpractice@oxfam.org.uk.

The information in this publication is correct at the time of going to press.

Oxfam GB, Oxfam House, John Smith Drive, Cowley, Oxford, OX4 2JY, UK.

ISBN: 978-1-78748-097-1

\section{OXFAM}

Oxfam is an international confederation of 20 organisations networked together in more than 90 countries, as part of a global movement for change, to build a future free from the injustice of poverty. Please write to any of the agencies for further information, or visit www.oxfam.org.

Oxfam America (www.oxfamamerica.org)

Oxfam Australia (www.oxfam.org.au)

Oxfam-in-Belgium (www.oxfamsol.be)

Oxfam Brasil (www.oxfam.org.br)

Oxfam Canada (www.oxfam.ca)

Oxfam France (www.oxfamfrance.org)

Oxfam Germany (www.oxfam.de)

Oxfam GB (www.oxfam.org.uk)

Oxfam Hong Kong (www.oxfam.org.hk)

Oxfam IBIS (Denmark) (http://oxfamibis.dk/)

Oxfam India (www.oxfamindia.org)

Oxfam Intermón (Spain) (www.intermonoxfam.org)

Oxfam Ireland (www.oxfamireland.org)

Oxfam Italy (www.oxfamitalia.org)

Oxfam Japan (www.oxfam.jp)

Oxfam Mexico (www.oxfammexico.org)

Oxfam New Zealand (www.oxfam.org.nz)

Oxfam Novib (Netherlands) (www.oxfamnovib.nl)

Oxfam Québec (www.oxfam.qc.ca)

Oxfam South Africa (www.oxfam.org.za) 